\title{
Application of numerical models to assess multi-source saltwater intrusion under natural and pumping conditions in the Great Maputo aquifer, Mozambique
}

\author{
Alberto Casillas-Trasvina ${ }^{1}$ (D) $\cdot$ Yangxiao Zhou $^{1,2}$ (D) Tibor Y. Stigter $^{1}$ (D) $\cdot$ F. E. F. Mussáa ${ }^{3} \cdot$ D. Juízo ${ }^{2}$
}

Received: 25 February 2019 / Accepted: 26 September 2019/Published online: 13 November 2019

(C) The Author(s) 2019

\begin{abstract}
Regional three-dimensional groundwater-flow and saltwater transport models were built to analyse saltwater intrusion in the Great Maputo area, southern Mozambique. Increased water demand has led to many private groundwater abstractions, as the local public water supply network has already reached maximum capacity. Pushing for new strategies to tackle the water-supply shortages exposes the aquifer system to saltwater intrusion from entrapped fossil saline groundwater and seawater. Previous attempts at modelling have been frustrated by data limitations. This study compiled all the available data to build the models, which were subsequently calibrated with observed heads, discharges and salt concentrations. The transport models were used to test hypotheses of potential sources of saltwater resulting in the current salinity distribution. Furthermore, scenarios were simulated to assess the impacts of sea-level rise and projected groundwater abstractions. Results show that saline groundwater is widely distributed in the aquifer's western sector, where it is a limiting factor for groundwater development, and seawater intrusion is a risk along the coastline. Newly constructed wells (46) along the Infulene River can be operated with some impacts of saltwater upconing and must be closely monitored. Although current groundwater abstractions $\left(60,340 \mathrm{~m}^{3} /\right.$ day $)$ are still small compared with groundwater recharge $\left(980,823 \mathrm{~m}^{3} /\right.$ day $)$, larger volumes of abstraction are feasible only when using a high number of production wells further away from the city with relatively low yields to avoid saltwater upconing. Capture of fresh groundwater upstream of discharge areas by wells for water supply is possible while maintaining groundwater discharges for groundwater dependent ecosystems.
\end{abstract}

Keywords Mozambique $\cdot$ Coastal aquifers $\cdot$ Saltwater intrusion $\cdot$ Numerical modeling $\cdot$ Scenario analysis

\section{Introduction}

Coastal groundwater resources are often the main freshwater source for densely populated areas, and at the same time vulnerable to climatic variations and anthropogenic pressures (e.g. Nelson 2013; Unsal et al. 2014; Michael et al. 2017; Post and Werner 2017). Projected demographic changes, population

Electronic supplementary material The online version of this article (https://doi.org/10.1007/s10040-019-02053-5) contains supplementary material, which is available to authorized users.

Alberto Casillas-Trasvina

JesusAlberto.CasillasTrasvina@ugent.be

1 IHE-Delft Institute for Water Education, PO Box 3015, 2601 DA Delft, The Netherlands

2 Hebei University of Geosciences, Shijiazhuang City, China

3 Eduardo Mondlane University (EMU), Maputo, Mozambique growth and economic development in coastal areas will lead to an increasing pressure on water resources, predicted to be further aggravated by climatic changes (e.g. Nicholls and Cazenave 2010; Bettencourt et al. 2012; Trung and Tri 2014). As a consequence, several threats can be triggered such as salinization of aquifer systems, increased pollution of the surface/subsurface water resources and impacts on the dependent ecosystems (Unsal et al. 2014; Post and Werner 2017). These negative impacts can be attributed to an increase in the water consuming activities and uncontrolled and unregulated groundwater abstractions, among others (Shah et al. 2000; Ferguson and Gleeson 2012; Alfaro et al. 2017). Salinization is largely caused by the dissolution of salt deposits (mainly halite), mixing with trapped seawater or recent seawater intrusion (Barlow and Reichard 2010; Tran et al. 2012; Badaruddin et al. 2017).

The Great Maputo coastal aquifer, located in a semi-arid developing region in southern Mozambique, is an example where groundwater is under pressure by economic development (World Bank 2017). Studies have been carried out to 
characterize the groundwater chemistry by Nogueira (2017) and Nogueira et al. (2019) and to assess climate impacts on the groundwater resources by Andreetta (2018). Nogueira (2017) showed that the fossil saltwater entrapped within geological formations in the northern and western part of the aquifer is the most probable source of saline groundwater, but this hypothesis has not been assessed through numerical modelling. Several studies applied numerical saltwater transport models for the simulation of saltwater intrusion and assessment of climatic and human impacts, including those presented for the Pioneer Valley in Australia (Werner and Gallagher 2006), for the coastal area in the Danish-German border adjacent to the Wadden Sea (Meyer et al. 2019), for the Neogene aquifer in Flanders, Belgium (Coetsiers et al. 2004), for Kiribati (Lal and Datta 2019) and Kish (Ataie-Ashtiani et al. 2013) Islands in the Pacific, and for Paleo-modelling of coastal saltwater, the Netherlands (Delsman et al. 2014). Variable density groundwater flow modelling can be used to assess the current state of the freshwater/saltwater distributions and to predict effects of future management decisions (Oude Essink et al. 2010).

For the Great Maputo aquifer, no groundwater flow or saltwater transport models have previously been developed. This study aims to develop such numerical tools to: (1) analyse the current saline groundwater distribution originating from different hypotheses of saltwater sources and (2) assess the potential of groundwater resources development under saltwater intrusion threats. For this purpose, groundwater flow and saltwater transport models were constructed and calibrated with groundwater level, stream discharges and salinity measurements. The study used groundwater flow and saltwater transport models to test hypotheses of saltwater sources and simulated current saltwater distributions in the Great Maputo area. The models were used for scenario analysis to assess impacts of saltwater intrusion under sea-level rise and future groundwater development. The results from model scenario analysis are very useful for sustainable development of groundwater resources in the area. The research enriches case study experiences of saltwater intrusion in coastal aquifers in the world.

\section{Materials and methods}

\section{Study area}

The Great Maputo coastal aquifer system is located in southern Mozambique and underlies an area of approximately $5,900 \mathrm{~km}^{2}$ including the most populated cities of the country: Maputo, Matola, Xinavane and Manhica (Fig. 1). The area is bounded to the east and south by the Indian Ocean, to the west by Libombos ridge and to the north by Incomati River. The population of the area was about 2.4 million inhabitants in 2016 (INE 2010). Population growth comes with a metropolitan expansion that current water supply and sanitation services are unable to follow. Both surface and groundwater resources are used to meet water demand. At the peak of the recent 3-year drought period the water supply had to be reduced by $40 \%$ of the regular capacity as a management strategy to face this situation (Mumbere 2018). Additionally, salinization inland is already a problem affecting the amount of available freshwater and the potential for exploitation. Uncertainty persists with regard to the origin of brackish and saline groundwater and surface water observed in the western and northern area, although mixing with fossil saltwater entrapped within geological formations appears to be the most plausible cause (Nogueira 2017). With the construction of 46 new groundwater abstraction wells by the Maputo Water Utility (FIPAG), the potential salinization risk rises due to the limited understanding of the system.

The topography of the area is mostly flat with elevations varying from 0 to $125 \mathrm{~m}$ relative to mean sea level (msl). The climate of the area is tropical savannah, characterized by wet and dry seasons, high temperature, medium rainfall and mild winters. Most of the rainfall occurs over the period from November to March with an average annual rainfall of about $600 \mathrm{~mm}$. The highest and lowest temperatures in the area are recorded during January and July, respectively, with average values around $27{ }^{\circ} \mathrm{C}$ (January) and $17^{\circ} \mathrm{C}$ (July). High values of potential evapotranspiration predominate over the entire year exceeding the average precipitation (Fig. 2). Several perennial and ephemeral rivers and streams originate from the area. The Incomati River being the largest river, is a transboundary perennial river shared by South Africa, Swaziland and Mozambique defined as river in the model to simulate water exchange between the river and groundwater. Ephemeral rivers and streams within the region such as Movene, Chambadejovo, Matola, Infulene, Cuenga and Chulavacane are considered as drains (see Fig. 1) to simulate seasonal groundwater discharges.

Two main aquifers can be distinguished, namely an unconfined aquifer built up of Quaternary fine-to-medium (recent and old) dune sands and a lower semi-confined aquifer consisting of fine-to-coarse sands partly cemented and rich in calcium carbonate, of Pleistocene age. Thicknesses range from 0 to $50 \mathrm{~m}$ and 50 to $60 \mathrm{~m}$, respectively. These two aquifers are separated by a clayey/silty aquitard (Ferro and Bouman 1987; Vicente et al. 2006; Chairuca et al. 2016), the presence and thickness of which is not uniform. All these units are underlain by a clayey/silty aquitard and by shallow marine deposits from the Tertiary. The semi-confined aquifer is primarily exploited for water supply for the metropolitan areas of the region. In the western sector the exploitation is limited by the observed high salinities in different locations of the aquifer (Nogueira 2017).

About 1,238 groundwater abstraction wells are distributed around Maputo and Matola cities, with much smaller numbers of wells in the rest of the area. The total abstraction rate is estimated to be $22 \mathrm{Mm}^{3} /$ year. These abstraction wells are operated by private water providers for the water supply in the 
(a)

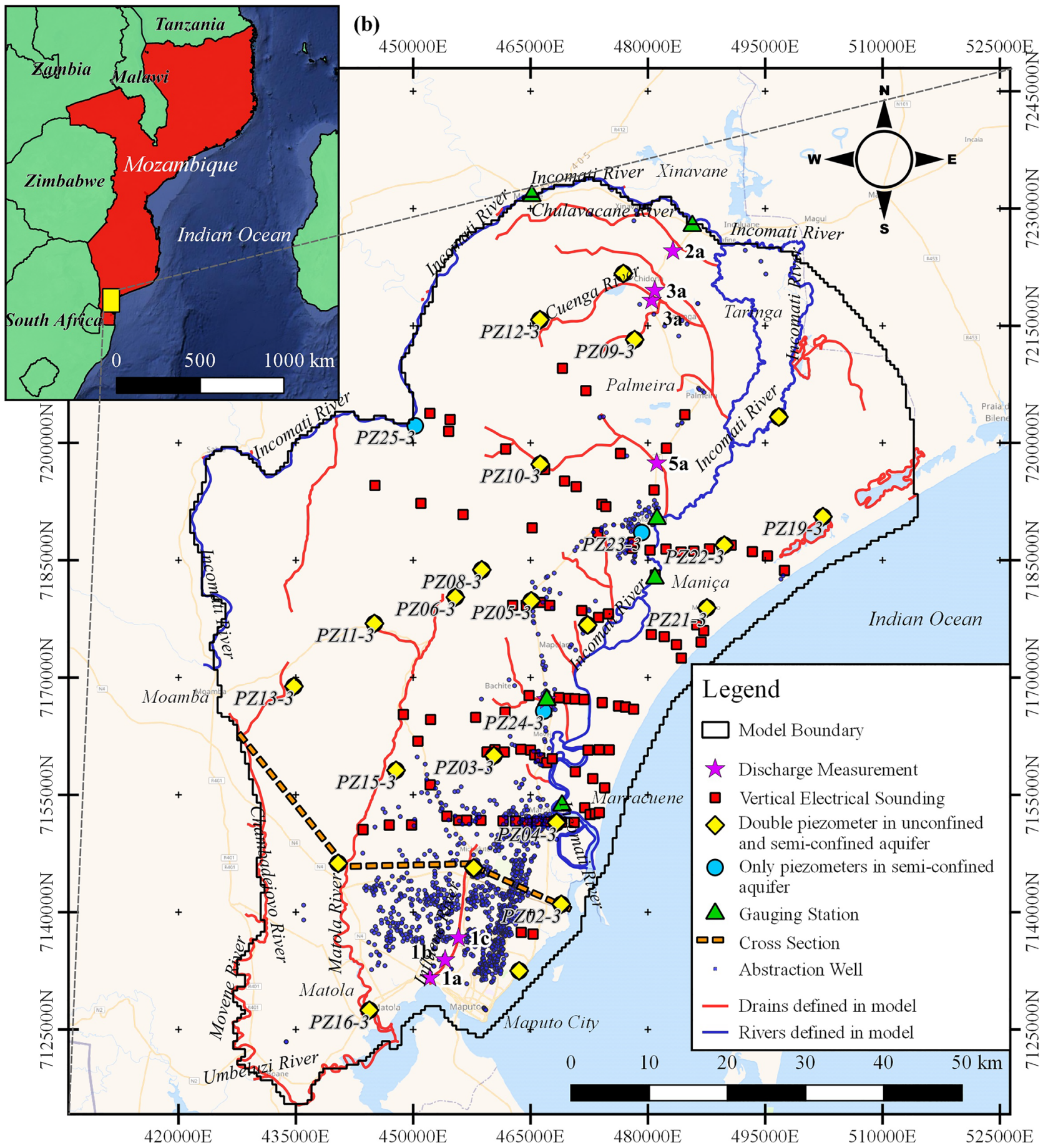

Fig. 1 Map of the study area indicating the model boundaries, and the locations of piezometers, abstraction wells, gauging stations and vertical electrical soundings; also shown are the drains and rivers defined in the models

peri-urban areas, whereby about $75 \%$ of wells have abstraction rates below $300 \mathrm{~m}^{3} /$ day.

\section{Modelling framework}

The objectives of the modelling studies were to test hypotheses of saltwater sources, to simulate impacts of saltwater intrusion under natural and pumping conditions, and to assess future groundwater development potentials. Since the main limiting factor for groundwater development is the risk of saltwater intrusion, coupled density dependent groundwater flow and saltwater transport models were used. The chloride concentration is usually used as an indicator for saltwater transport modelling since chloride is a conservative constitute and easier to measure. However, measurements of chloride concentrations are only available in some observation wells in recent years and in 


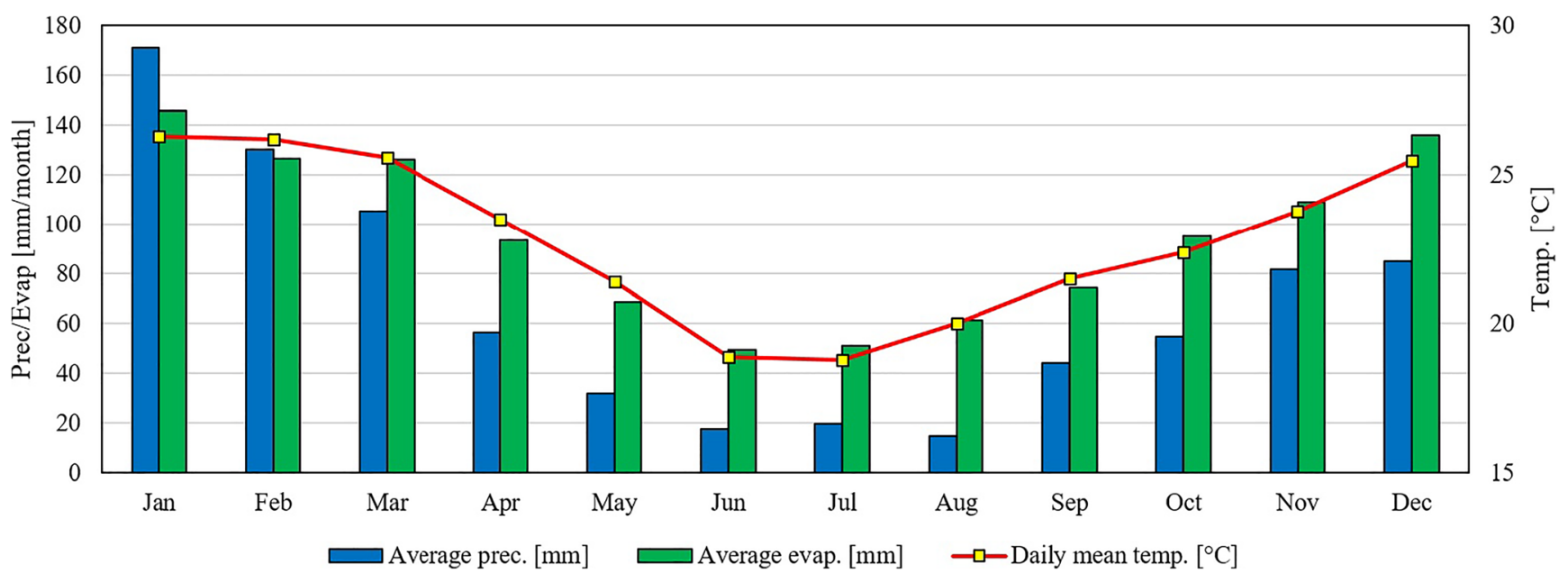

Fig. 2 Average monthly precipitation, temperature and potential evapotranspiration for the Great Maputo region, for the years 1961-1990

abstraction wells in 2017. A large amount of groundwater abstraction started in 1968 and may have triggered saltwater intrusion. The chloride transport model needs to be run from 1968 to 2017 to simulate possible impacts. Initial condition of chloride concentrations in 1968 must be specified. There were no chloride measurements in 1968 and the chloride concentrations had to be created with a chloride evolution model. The chloride evolution model was run over 100 years from 1869 to 1968 from the assumed saltwater sources until an equilibrium chloride distribution was reached. Therefore, a step-by-step modelling approach was adopted in this study. First, a steady-state groundwater flow model was constructed with computed average net recharge and discharge over a period of 6 years (2011-2017), and calibrated with measured hydraulic heads and measurements of discharge (point measurements in 2018) for which data were available. Second, a chloride transport model was constructed to simulate saline groundwater evolution in the last 100 years, from 1869 to 1968, under different hypotheses of saltwater origin under natural conditions. The steady-state natural groundwater flow condition was assumed for the simulation period. The chloride evolution model created the initial conditions for a subsequent 50-year transport model from 1968 to 2017 under pumping conditions. The computed $\mathrm{Cl}$ concentrations were compared with measurements of recent years. Third, scenarios analysis models were constructed to assess groundwater development in relation to saltwater intrusion impacts.

The groundwater flow model was constructed using the three-dimensional (3D), block-centred, finite-difference code MODFLOW-2005 (Harbaugh et al. 2005). The $\mathrm{Cl}$ transport model was constructed using the variable-density groundwater flow code SEAWAT (Langevin et al. 2008). The model preparation and result visualization were done with a graphic modelling environment Processing Modflow (PM8; Chiang 2005). The SEAWAT code was chosen to simulate saltwater transport since it acts as a postprocessor for MODFLOW. Furthermore, SEAWAT is capable of simulating density- dependent flow and saltwater transport and is widely applied (Rojas and Dassargues 2007; Jaworska-Szulc 2009; Bakker and Schaars 2010; Alfaro et al. 2017; Rödiger et al. 2017; Sahoo and Jha 2017; Meyer et al. 2019). Additionally, MODFLOW and SEAWAT are both public domain computer programs, distributed freely by the US Geological Survey (Harbaugh et al. 2005; Langevin et al. 2008). The groundwater flow model was calibrated first with trial-and-error and then using automated parameter estimation with PEST (Doherty 2016) for groundwater heads and discharge measurements. A sensitivity analysis was carried out with PEST to identify most sensitive parameters and measurements. The $\mathrm{Cl}$ transport model took into account advection and dispersion as transport processes considering density variations in relation to $\mathrm{Cl}$ concentration changes (see section 'Model parameters'). This relation is defined by Eq. (1) where DRHODC is the slope of the linear equation of state that relates fluid density change $\left(\partial \rho\right.$, in $\left.\mathrm{kg} / \mathrm{m}^{3}\right)$ to solute concentration change $(\partial C$, in $\mathrm{mg} / \mathrm{L}$; Langevin et al. 2008). The calibration of the saltwater transport model was carried out manually by testing hypotheses of salinity sources distributed in the area and comparing against observed $\mathrm{Cl}$ concentrations in recent years.

$\mathrm{DRHODC}=\frac{\partial \rho}{\partial C}=\frac{1025-1000}{19,000-100)}=0.00132$

\section{Conceptual model}

The aquifer system was conceptualized into four hydrogeological layers (Fig. 3) by Nogueira (2017) based on a previous study (Hydroconseil and We-Consult 2011) and additional hydrochemical information. The top layer constitutes a regional phreatic aquifer consisting of young sand dunes east of Incomati River, clay-rich alluvial deposits in the Incomati Valley, and old sand dunes in between Incomati 


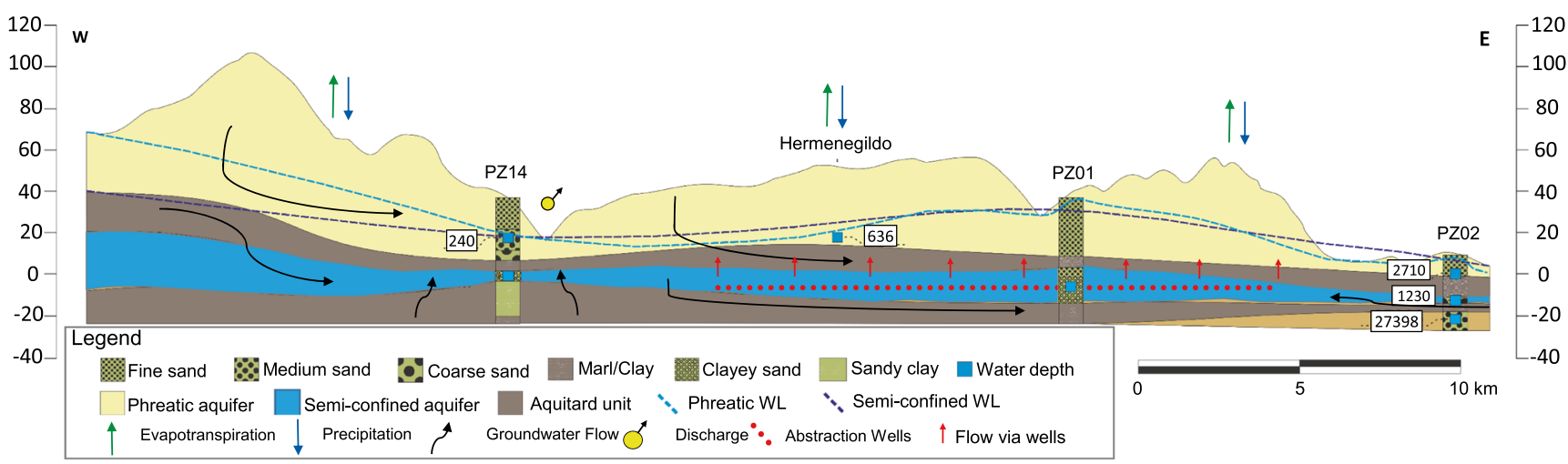

Fig. 3 Conceptual model profile of the groundwater system West to East (adapted from Nogueira 2017)

and Matola rivers (for location see Fig. 1) A regional aquitard built up of clay and silt separates the phreatic aquifer from the lower semi-confined aquifer. A semi-confined aquifer is found below the silt/clay layer, consisting of fine-to-coarse sands rich in calcium carbonate, also bordered at the bottom by an aquitard of clays and silts. The intermediate aquitard is not found everywhere in the area; where it is absent a single thick unconfined aquifer is formed (Ferro and Bouman 1987; Hydroconseil and We-Consult 2011; Nogueira 2017). Groundwater at the bottom aquitard (everywhere) and intermediate aquitard (mostly in the west and near the coast) was found to be brackish (chloride concentration between 300 and $10,000 \mathrm{mg} / \mathrm{L}$ ) to saline (chloride concentration higher than $10,000 \mathrm{mg} / \mathrm{L}$ ) (Stuyfzand 1986), providing a source of saltwater that needs to be included in the saltwater transport model.

Groundwater recharge is formed mainly by direct infiltration of precipitation in sandy areas. Leakage from the Incomati River in the north-western area may also take place. Natural groundwater discharge occurs through evapotranspiration and discharge to streams, rivers and the sea. Groundwater abstraction also takes place albeit at relatively low rates. The presence of saline groundwater has been observed in the northern area, the area west of Matola River (see Fig. 1), and along the coastline. The hypotheses of saltwater sources include entrapped fossil saltwater in the first aquitard in these areas, saline groundwater at the bottom aquitard, and seawater (Nogueira 2017). These hypotheses were tested during the transport model calibration.

\section{Model construction}

\section{Model domain and boundary conditions}

The modelled area was discretized into a regular model grid of 224 rows and 248 columns resulting in cells with dimensions of $500 \mathrm{~m} \times 500 \mathrm{~m}$. The four model layers were used to represent the top phreatic aquifer, the first aquitard, the semiconfined aquifer and the bottom aquitard. The layer thicknesses were obtained by interpreting scatter point data from 97 vertical electrical soundings and 1,131 geological boreholes using the Kriging interpolation method. The elevation of the top of the phreatic aquifer was obtained through 30$\mathrm{m}$ DEM data. The constructed model should be regarded as the regional groundwater flow and transport model which is adequate to simulate regional flow and transport patterns, but may not be sufficient to describe freshwater/saltwater transition zone accurately.

The model boundaries can be found in the Fig. 1. The north boundary follows the Incomati River and was simulated as a head-dependent flow boundary using the MODFLOW River package in the first model layer, while the remaining model layers were defined as no-flow boundaries. The east and south boundaries follow the coastline, which was simulated as a head-dependent flow boundary in the first model layer using the MODFLOW GHB package, and as a constant head boundary in the remaining layers. The western border of all model layers was defined as a no-flow boundary following the surface-water divide to the west and no inflow at the neighbouring hard rock formations.

\section{Hydrological stresses}

The hydrological stresses include precipitation recharge, interactions with the Incomati River, discharge to streams, and groundwater abstraction. Groundwater recharge from precipitation infiltration was computed with a daily soil-water balance model using a spreadsheet model. Since the soil-water balance model includes interception and evapotranspiration, the computed recharge value can be considered as net groundwater recharge. In total, 12 recharge zones were delineated based on topography, soil types, and land use (Fig. 4). The computed annual recharge rates vary from 16 to $17 \mathrm{~mm} /$ year in the west area, to $60-100 \mathrm{~mm} /$ year in the sand dunes, and about $50 \mathrm{~mm} /$ year in the river valleys (Nogueira 2017).

The Incomati River flows from the north to the south cross the model area. Measurements indicate that groundwater 
Fig. 4 Recharge zones and recharge values

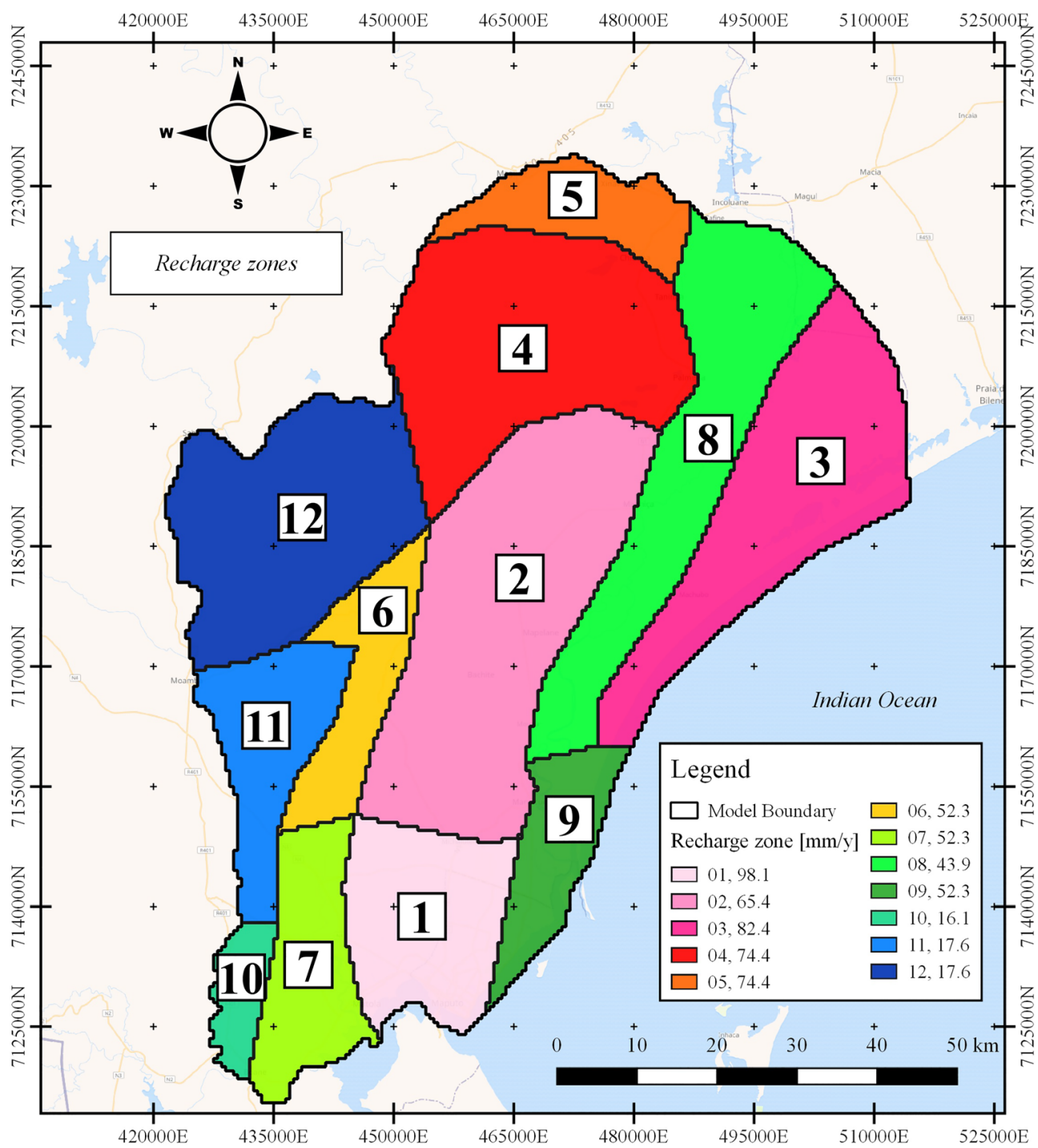

discharges to the river in this section. The River package in MODFLOW was used to simulate groundwater discharge to, and possible recharge, from the river. There are a number of smaller streams that receive groundwater discharge, for which the MODFLOW Drain package was used. A field campaign was carried out in the beginning of the rainy season of $2017 / 2018$ to determine surface water discharges (Table 1).
These discharge values were used to compare with the modelcomputed discharges during the model calibration.

Locations and abstraction rates for 1,238 wells were included in the model. The well screens range in elevations from 40 to $-65 \mathrm{~m}$ above msl. A model cell may consist of a number of wells. These abstraction wells were clustered into one model well. In the end, a total of 735 model wells abstracting a

Table 1 Stream discharges $(Q)$ and electrical conductivity (EC) values measured during the field campaign in February, 2018

\begin{tabular}{lllcl}
\hline Note & Drain & EC $[\mu \mathrm{S} / \mathrm{cm}]$ Observed & $Q\left[\mathrm{~m}^{3} / \mathrm{s}\right]$ Estimated & Coding \\
\hline Discharging into the sea & Infulene stream & $1,953-940$ & 0.25 & $1 \mathrm{a}-1 \mathrm{c}$ \\
Discharging into Incomati River & Chulavacane stream & 3,060 & 0.82 & $2 \mathrm{a}$ \\
& Cuenga stream and wetlands & 2,900 & 1.20 & 0.01 \\
& Wetland zone & 12,000 & 0.04 & $5 \mathrm{a}$ \\
& Branch 6 stream & 450 & $5 \mathrm{a}$ \\
\hline
\end{tabular}


total of 22 million $\mathrm{m}^{3}$ /year were allocated. Ferro and Bouman (1987) mention the semi-confined aquifer as a more productive aquifer when compared with the unconfined aquifer, having potential to solve water issues, therefore, abstraction wells were entered into the third model layer (semi-confined aquifer) representing the total abstraction rate in the region. The abstractions were simulated using the MODFLOW Well package.

\section{Model parameters}

According to geology and borehole data, six parameter zones were delineated (Fig. 5) for the two aquifers. The initial hydraulic conductivity values were estimated from a limited number of pumping tests and empirical values of lithology. The vertical hydraulic conductivities were assumed to be $10 \%$ of the horizontal values, as usually defined for porous medium. The two aquitards were simulated as homogeneous units with estimated horizontal and vertical hydraulic conductivities based on empirical values of lithology. These parameter values were adjusted during the model calibration and optimized by PEST (lower limit was taken as half and upper limit as twice of the initial values). Results on horizontal hydraulic conductivities are presented in Table 2.

\section{Saltwater sources}

A number of saltwater sources were taken into consideration for the saltwater evolution model. The hypotheses presented by Nogueira (2017) regarding entrapped fossil saline water in aquitard formations were tested and combined to the known natural saltwater sources:

1. Hypotheses of potential fossil saline waters entrapped in different units at various locations:
Fig. 5 Zones of horizontal hydraulic conductivities

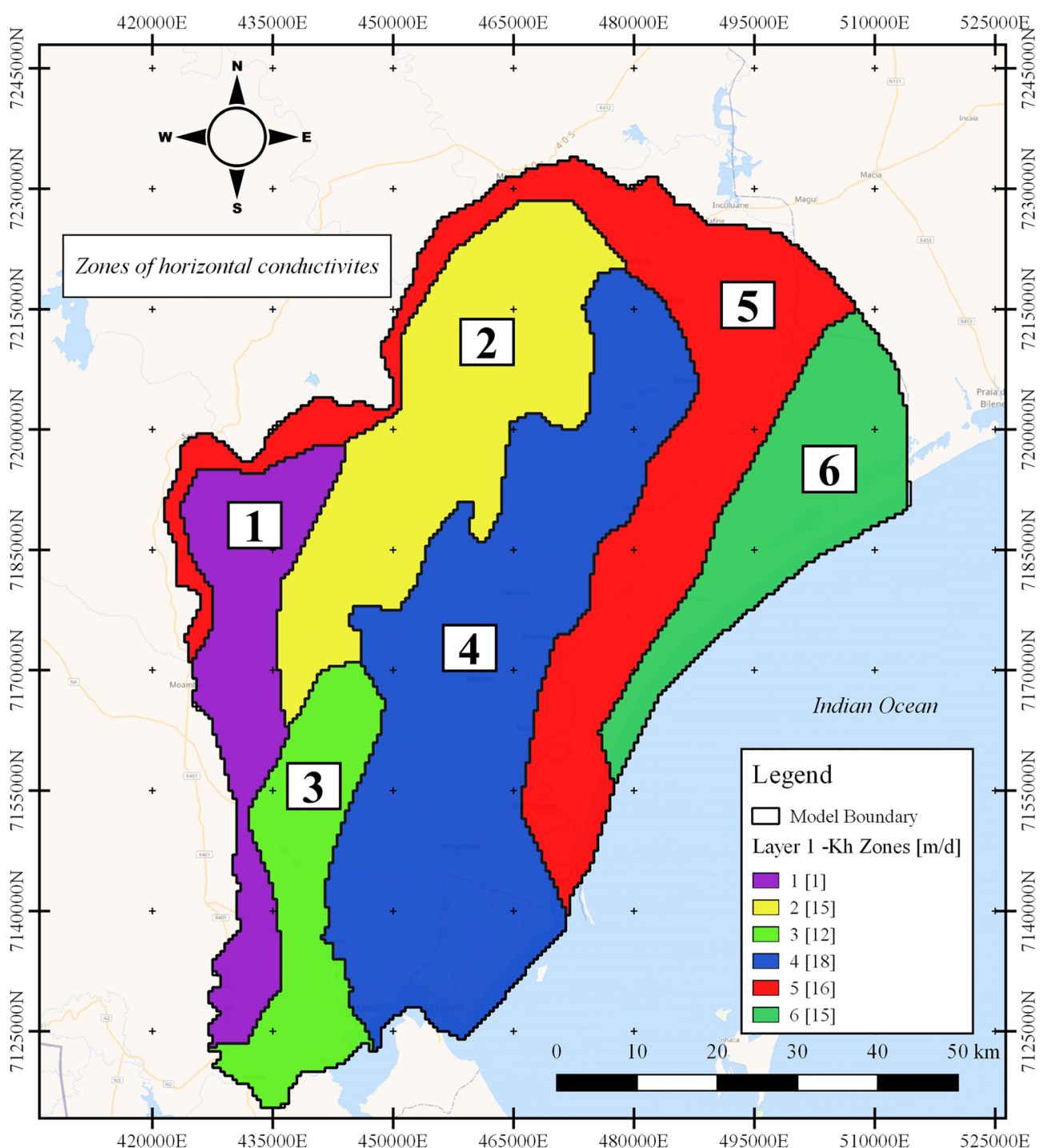


Table 2 Horizontal hydraulic conductivities after calibration for different zones per layer and values for effective porosity and dispersivity

\begin{tabular}{|c|c|c|c|c|c|c|c|c|c|c|}
\hline \multirow[t]{2}{*}{ Model layer } & \multicolumn{6}{|c|}{$\begin{array}{l}\text { Horizontal hydraulic conductivity }\left(K_{\mathrm{h}}\right) \text { zones } \\
{[\mathrm{m} / \text { day }]}\end{array}$} & \multirow[t]{2}{*}{ Effective porosity } & \multicolumn{3}{|c|}{ Dispersivity [m] } \\
\hline & 1 & 2 & 3 & 4 & 5 & 6 & & Longitudinal & Transversal horizontal & Transversal vertical \\
\hline Unconfined aquifer & 1 & 15 & 12 & 18 & 16 & 15 & 0.30 & 10 & 0.1 & 0.01 \\
\hline Aquitard (layer 2) & 0.5 & 1 & 1 & 1 & 0.1 & 1 & 0.15 & 10 & 0.1 & 0.01 \\
\hline Semi-confined aquifer & 1 & 15 & 12 & 18 & 10 & 15 & 0.30 & 10 & 0.1 & 0.01 \\
\hline Aquitard (layer 4) & 0.25 & 0.25 & 0.25 & 0.25 & 0.25 & 0.25 & 0.15 & 1 & 0.1 & 0.001 \\
\hline
\end{tabular}

a. The bottom aquitard layer (the 4th model layer) as a distributed source with varying chloride concentrations, estimated by vertical electrical sounding (VES) data between 40 and $3,325 \mathrm{mg} / \mathrm{L}$

b. The middle aquitard and semi-confined aquifer in the western area of Matola River and near the northeast area, identified from VES and EC measurements between 11 and 2,092 $\mathrm{mg} / \mathrm{L}$

2. General-head boundary and constant-head cells with a constant chloride concentration of $19,400 \mathrm{mg} / \mathrm{L}$ representing the sea

3. River chloride concentrations from a previous water sampling analysis along the Incomati River carried by Okello et al. (2012)

4. Recharge precipitation $(p)$ distributed over the defined recharge zones as a function of the distance to the sea. An estimation of the chloride concentration in rain water, $\mathrm{Cl}_{(p+d)}(\mathrm{mg} / \mathrm{L})$, was be done from Hutton (1976) using:

$\mathrm{Cl}_{(p+d)}=35.45 \cdot\left(\frac{0.99}{d^{0.25}}-0.23\right)$

where $d$ is the distance in $\mathrm{km}$ from the sea. The chloride concentration in the recharge water was approximated by dividing the recharge/precipitation ratio in order to account for changes in concentration due to evapotranspiration.

In order to convert EC values to chloride concentrations, regression analysis was used with groundwater samples from Nogueira (2017). The regression equations are as follows:

For $\mathrm{EC} \leq 1500 ; \mathrm{Cl}=0.1569 \mathrm{EC}-1.6$

For $1500<\mathrm{EC}<2500 ; \mathrm{Cl}=0.2142 \mathrm{EC}-76.5$

For $\mathrm{EC} \geq 2500 ; \mathrm{Cl}=0.3887 \mathrm{EC}-561.3$

\section{Model calibration and sensitivity analysis}

The steady-state groundwater flow model was constructed and calibrated using automated parameter estimation with PEST (Doherty 2016) using groundwater head and discharge measurements. A sensitivity analysis was carried out with PEST to identify most sensitive parameters and measurements. Model performance was evaluated using a set of statistical indicators: mean error (ME), mean absolute error (MAE), root mean squared error (RMSE), scaled root mean squared error (SRMSE), and coefficient of determination $\left(R^{2}\right)$. An iterative procedure was used to calibrate the $\mathrm{Cl}$ transport models by testing hypotheses of saltwater sources in the 100-year $\mathrm{Cl}$ evolution model and compared with $\mathrm{Cl}$ measurements in the 50-year transport model. The initial $\mathrm{Cl}$ concentrations in the 100 -year $\mathrm{Cl}$ evolution model were adjusted until the 50-year $\mathrm{Cl}$ transport model could reproduce the measured $\mathrm{Cl}$ distributions in 2017.

\section{Formulation of scenarios}

The calibrated numerical models were applied to simulate three scenarios compared against a benchmark model. These scenario simulations were run for 50 years from 2017 until 2066 in consideration of the long time required for saltwater transport to reach an equilibrium state. The groundwater flow model was kept at steady state while the $\mathrm{Cl}$ transport model was run with a constant transport step of 30 days. The computed $\mathrm{Cl}$ concentrations at the end of every year were used for comparison.

\section{Benchmark situation}

Normal hydrological conditions and current abstractions were used in the simulation models. The $\mathrm{Cl}$ transport model was run from 2017 to 2066 to simulate saline groundwater head and salinity distributions in the next 50 years. These model results provide benchmarks to compare the scenario model results.

\section{Scenario 1: planned new abstractions}

Maputo Water Utility has constructed 46 new abstraction wells to cover the water supply needs in the main cities and peri-urban areas. These new abstraction wells are mostly concentrated in four groups along the Infulene River (see location in Fig. 1) with screens in the semi-confined aquifer. The initial abstraction from these new wells is planned to be $12.6 \mathrm{Mm}^{3} /$ year. The total abstraction rate will increase to $34.6 \mathrm{Mm}^{3} /$ year. Apart from the 
abstraction change, normal hydrological conditions were used in this scenario model as in the benchmark model.

\section{Scenario 2: sea-level rise}

According to Serdeczny et al. (2017), sea-level rise is not uniform across Sub-Saharan Africa. On their projection, specifically for the Maputo Region, a sea level rise of 0.4-1.15 m is expected with an average of $0.75 \mathrm{~m}$ by the end of the century. This projected sea level rise presents a potential risk of seawater intrusion in the coastal zone. In considering uncertainties in predicting level rise (Schubert et al. 2006; Rahmstorf 2007), a linear increase of sea level from 0 to $1.0 \mathrm{~m}$ was applied to the coastline model boundaries (both in GHB and constant head) to simulate any possible impact.

\section{Scenario 3: projected water demand increase}

Currently approximately 2.4 million people live in the Great Maputo area and the projected population growth is expected to reach 5 million by 2068 (INE 2012). Various options are being considered to meet the future increase in demand, among which is increasing groundwater abstraction. This option requires an extra abstraction of $85,000 \mathrm{~m}^{3} /$ day by 2068 to cover the projected water demands, if no other alternative sources are found. The total abstraction rate will increase to $64.8 \mathrm{Mm}^{3} /$ year. The impact of this scenario was evaluated with the models using the existing abstraction wells and considering unchanging climatic and hydrological conditions. In order to implement this scenario, the abstraction rates from the planned 46 new wells and 368 existing wells were increased by $30 \%$. These 368 existing wells were selected according to the following criteria: (1) the wells are located outside of the heavily abstracted urban area; (2) their current abstraction rates are less than $250 \mathrm{~m}^{3} /$ day and there are possibilities for increase; (3) the selected wells are scattered spatially to avoid saltwater upconing.

\section{Results}

\section{Model calibration}

\section{Groundwater flow model}

The steady-state groundwater flow model was calibrated by trial-and-error in the beginning and subsequently optimized with PEST. Groundwater recharge rates, river and drain conductance, and hydraulic conductivity were subject to changes in order to achieve the best fit of calculated and observed groundwater heads. The scatter plot of calculated groundwater heads against observed heads, as well as the statistics of the model calibration are shown in Fig. 6. For both phreatic and semi-confined aquifers, calculated groundwater heads follow the trend of observed heads with a high correlation coefficient (0.9). Although the root mean squared error (RMSE) is relatively large, it is only $9 \%$ of the total variation of groundwater heads in the area. Therefore, the calibrated groundwater flow model was considered acceptable to analyse groundwater flow and water balances, and further construct the $\mathrm{Cl}$ transport model.

The calibrated recharge values in Fig. 7 represent an average of $8.4 \%$ of the annual precipitation for the whole modelled area, significantly lower than the previously computed average recharge of $15 \%$ by Nogueira (2017). These higher recharge values, when applied to the groundwater model, resulted in higher hydraulic heads and stream discharges than measured in the current study, and therefore had to be lowered. The computed stream discharges were also compared with measured discharges. The computed discharges match measured discharges well in most measured locations (i.e. Infulene, Chulavacane, Movene, Cuenga). Nevertheless, large disagreements were found in some locations (i.e. Matola and one unnamed small stream). These aspects will be further addressed in the discussion.

Contour maps of the computed groundwater heads are shown in Fig. 8 for the phreatic (Fig. 8a) and semi-confined (Fig. 8b) aquifers. Regional groundwater flow patterns are similar in phreatic and semi-confined aquifers controlled by groundwater discharges. Groundwater flow in general is from inland towards the sea, rivers and streams. Most of the groundwater is discharged to Incomati River, inland streams and the sea. Following the approach presented by De Luca et al. (2019), differences of groundwater levels between the phreatic and the semi-confined aquifers were computed and classified into three categories to determine potential recharge, discharge and horizontal flow areas. The results for the potential groundwater leakages between the phreatic aquifer and the semi-confined aquifer are shown in Fig. 9. In most areas, groundwater flow is horizontal; downward flow occurs in the area where a large amount of groundwater abstraction takes place in the semi-confined aquifers. In the discharge areas along the rivers, streams and the coastline, groundwater in the semi-confined aquifer flows upward to the phreatic aquifer.

\section{Sensitivity analysis}

The composite scaled sensitivity (CSS) summarizes all the sensitivities for one parameter (Hill and Tiedeman 2007). CSS can be used to compare the amount of information provided by different types of parameters. Model simulation results are more sensitive to parameters with larger CSS values. The computed CSS with PEST is presented in Fig. 10. It can be seen that the recharge in zone 2 (rch_2) was identified as the most sensitive parameter. It was already shown in Fig. 7 that the recharge value of zone 2 obtained through model calibration was significantly lower than that previously considered values. Parameter sensitivity was also high for 


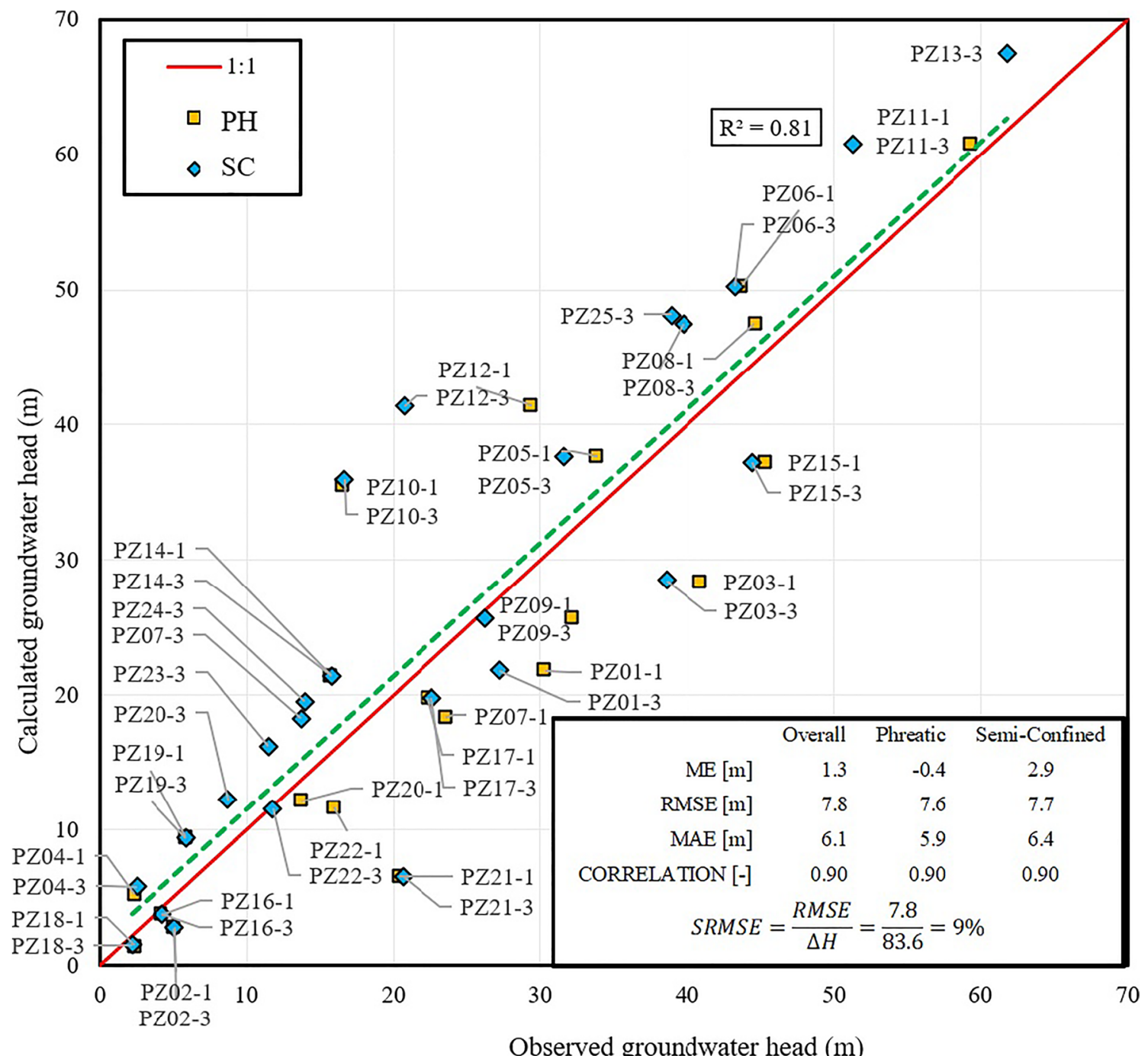

Fig. 6 Scatter plot of calculated groundwater head against observed groundwater head for the phreatic aquifer (PH, yellow squares) and semi-confined aquifer (SC, blue diamonds) of the Great Maputo area; also shown are the statistics of the model calibration

recharge in zone 4 (rch_4) and horizontal conductivities of layers 3 and 1 (hk_34 and hk_14, respectively), with considerably large CSS values, followed by several of the other recharge zone values. The model results were least sensitive to the river and drain conductance, with exception of drain 151, which corresponds to Matola River-see Fig. S1 in the electronic supplementary material (ESM).

\section{Saline groundwater model}

The $\mathrm{Cl}$ transport model was manually adjusted by changing saltwater sources and transport parameters in order to match measured $\mathrm{Cl}$ concentrations in 2017. Since there are no continuous measurements of $\mathrm{Cl}$ concentration from monitoring wells, only sporadic measurements were used to check computed and measured values in 2017. Figure 11 compares computed and measured $\mathrm{Cl}$ concentrations in 2017. Although the $\mathrm{Cl}$ transport model is able to compute values in the observed range, the lack of long-term $\mathrm{Cl}$ concentration measurements does not allow a full calibration of the saline groundwater flow model. Furthermore, there are only a few measurements in the brackish/saline water zones. The installation of 15 CTD Divers (automatic data loggers for electrical conductivity, temperature and pressure) in 2017 provides data for better model calibration in the future; however, it is clear that the number of monitoring sites is still low for such a large area.

The spatial distribution of $\mathrm{Cl}$ concentrations in the phreatic and semi-confined aquifers are plotted in 2017. $\mathrm{Cl}$ concentrations are much higher in the semi-confined aquifer and the most saline groundwater is found west of the Matola River and in the northernmost sector. The upconing of saline water from the bottom layer to the semi-confined aquifer around the main abstraction area of the cities is also visible. The presence of saline groundwater in the phreatic aquifer in the western Matola River and northern area is also the result of saltwater flow from the underlying aquitard and semi-confined aquifer (see Fig. 9). 


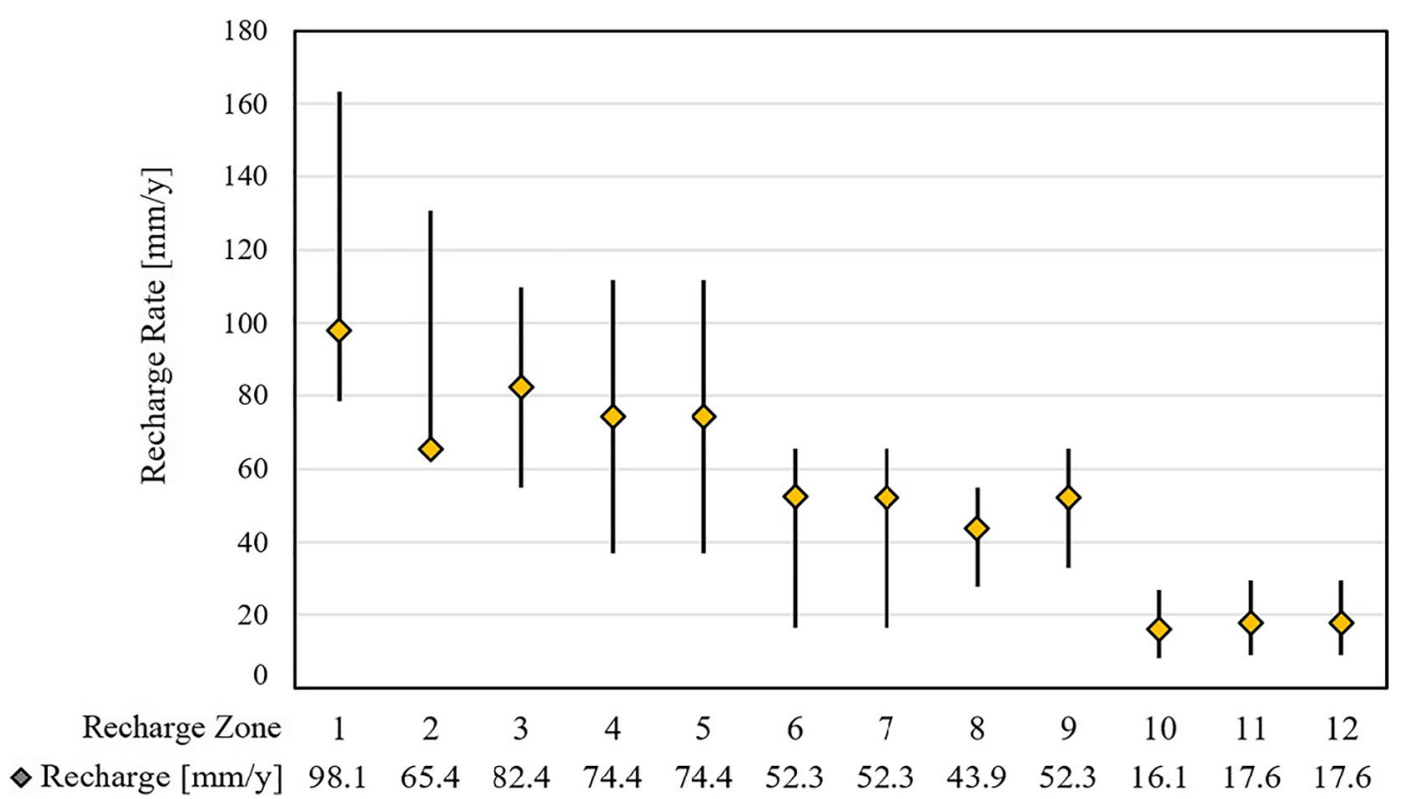

Fig. 7 Upper and lower recharge rates used during the automated calibration, defined based on values from previous studies

\section{Water budget}

The yearly average water budget for the entire aquifer system is presented in Table 3. Because of the density-driven flow, the SEAWAT transport model computed a groundwater balance slightly different from the MODFLOW model. The computed water budget shows that net recharge from precipitation is the major inflow and accounts for $97 \%$ of the total recharge. Groundwater discharges are spread, to discharge to streams (44\%), discharge to the Incomati River (29\%), and into the sea $(21 \%)$. Groundwater abstraction is relatively low and accounts for only $6 \%$ of the total discharge; additionally, seawater

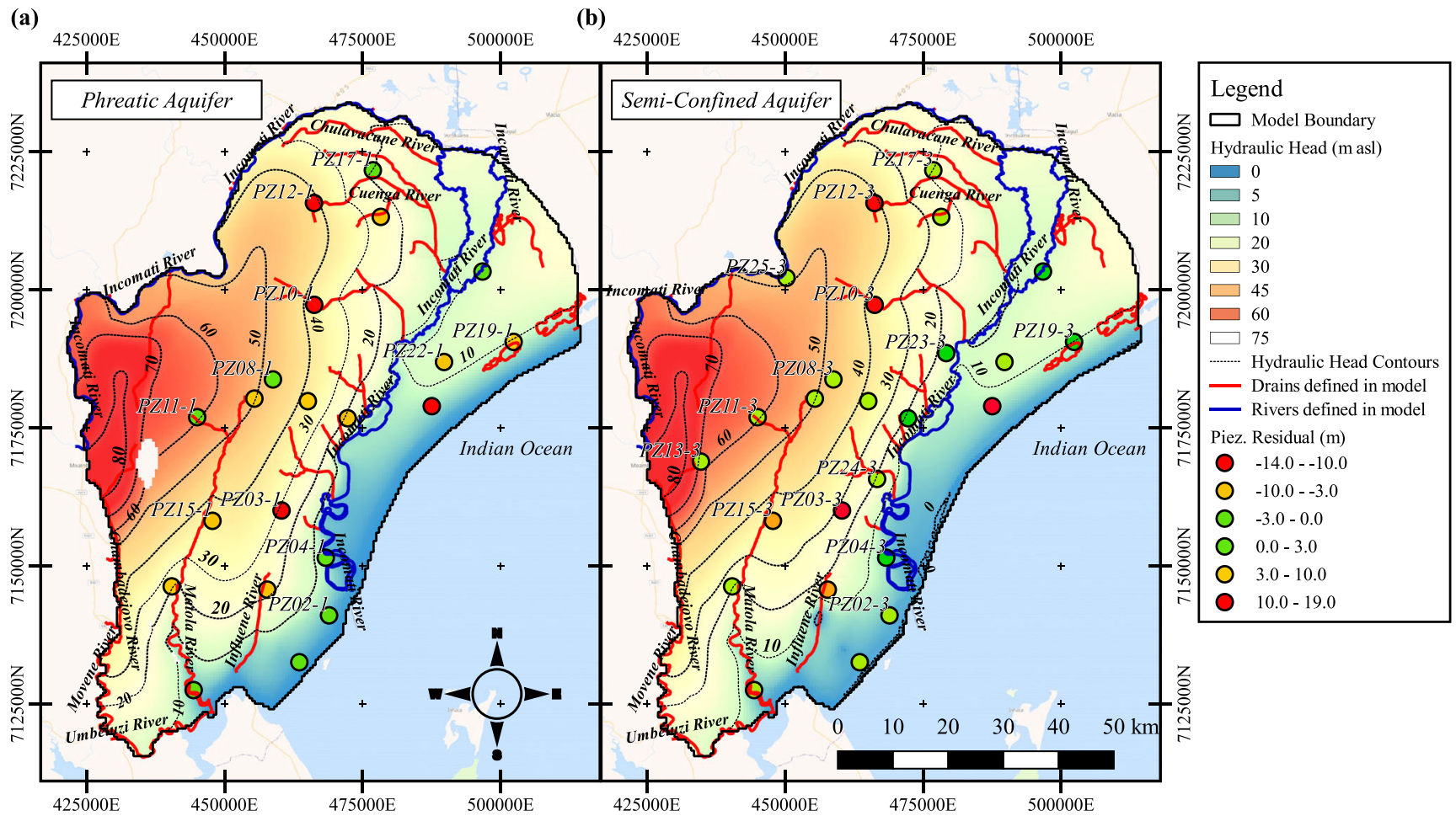

Fig. 8 Contour map of hydraulic head distribution and residuals for $\mathbf{a}$ phreatic and $\mathbf{b}$ semi-confined aquifers 
Fig. 9 Downward flow, upward flow and horizontal flow areas determined by computing differences of hydraulic heads between the phreatic aquifer and the semi-confined aquifers
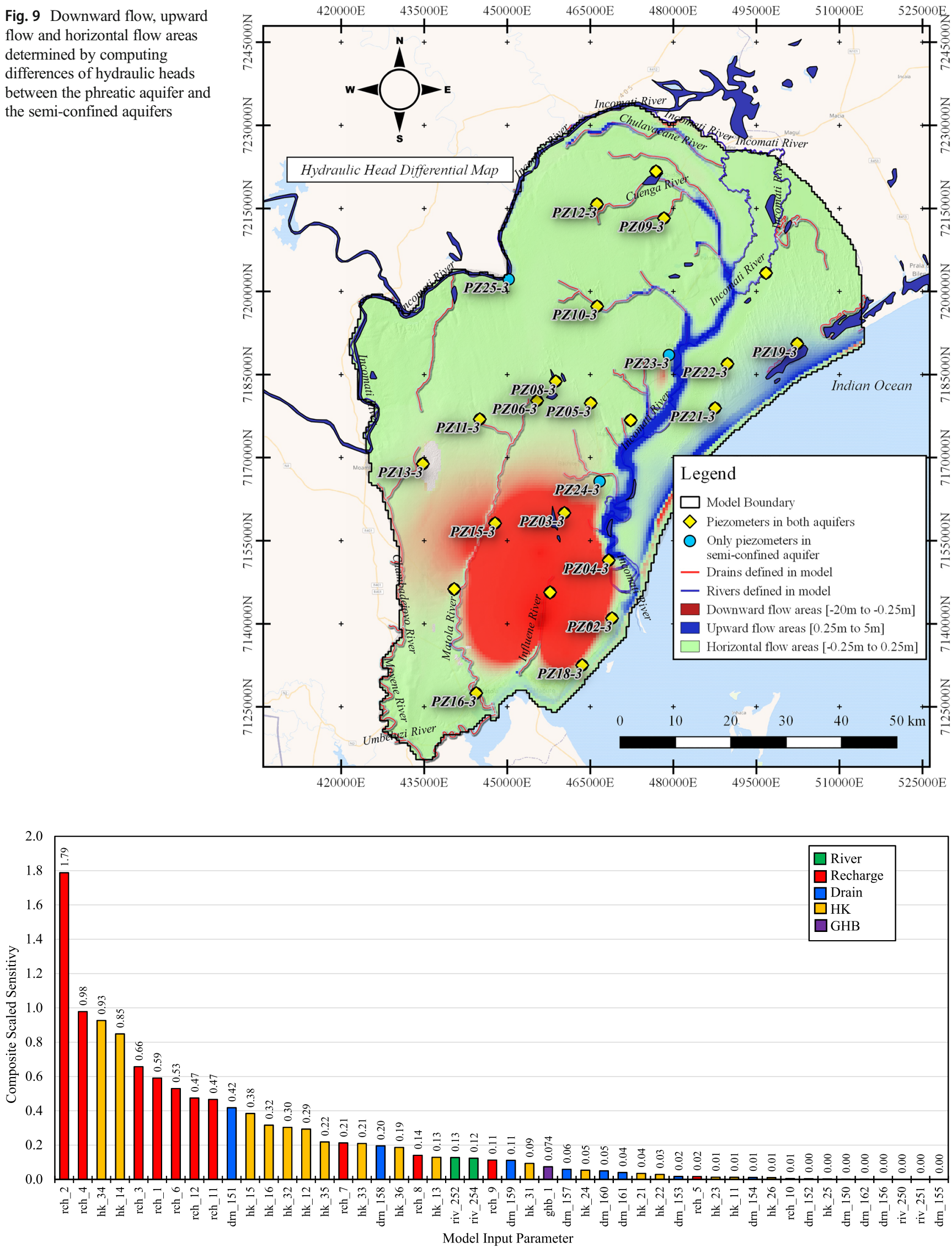

Fig. 10 Composite scaled sensitivity for model parameters; for locations of recharge and horizontal hydraulic conductivity zones see Figs. 4 and 5 
Fig. 11 Scatter plot of calculated against observed $\mathrm{Cl}$

concentrations for the phreatic aquifer (PH, yellow squares) and semi-confined aquifer (SC, blue diamonds); also shown are the statistics of model calibration

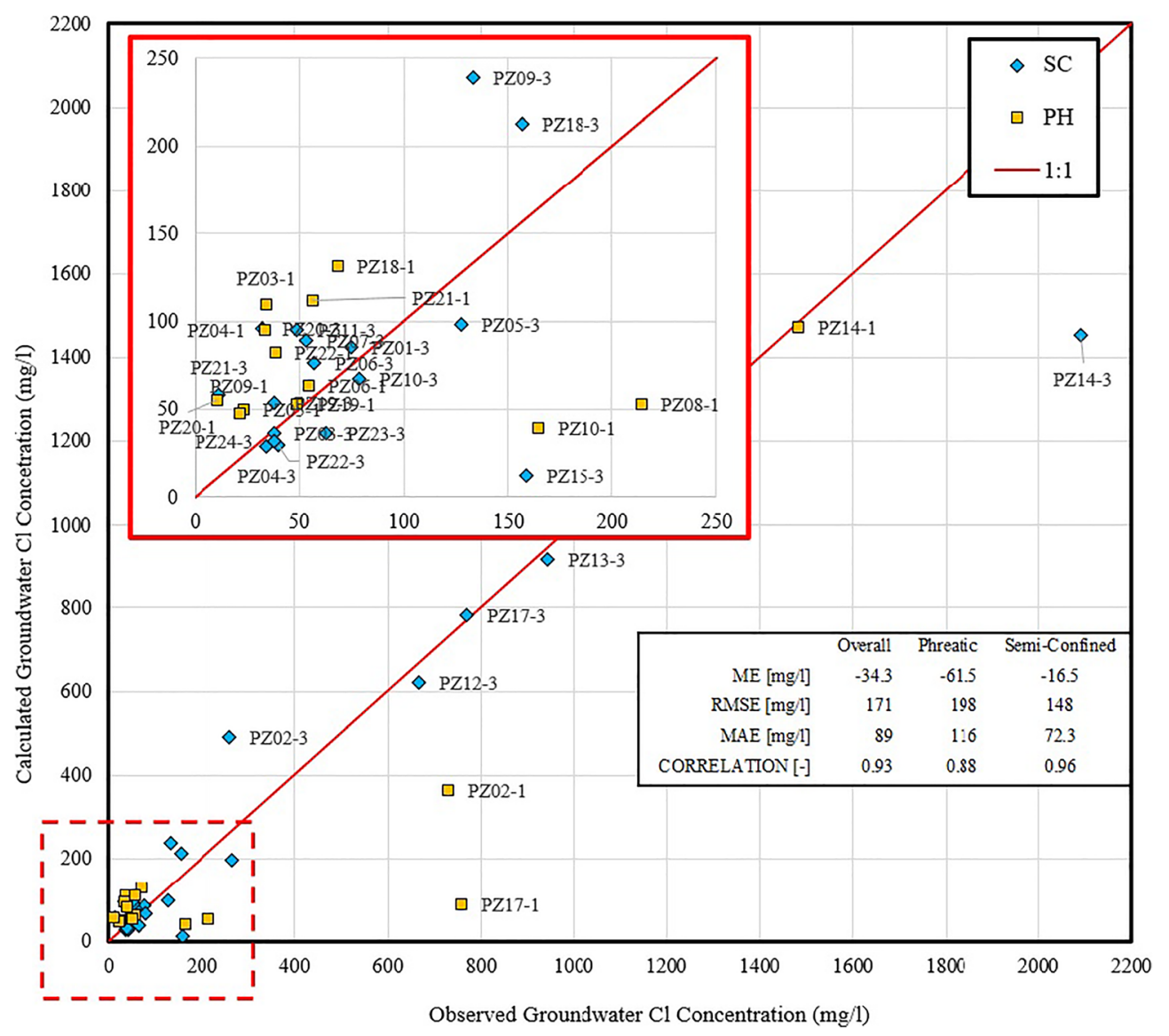

intrusion occurs along the coastlines accounting for $1.5 \%$ of the total inflow.

\section{Simulation of scenarios}

The scenarios were simulated with calibrated groundwater flow and $\mathrm{Cl}$ transport models. The computed $\mathrm{Cl}$ concentrations in 2017 were used as initial concentrations. The scenario models were run for 50 years. The hydrological stresses were assumed as

Table 3 Model-derived steady-state groundwater budget after the calibration process by SEAWAT

\begin{tabular}{lll}
\hline Flow terms & In $\left[\mathrm{Mm}^{3} /\right.$ year $]$ & Out $\left[\mathrm{Mm}^{3} /\right.$ year $]$ \\
\hline Discharge to the sea & - & 74.8 \\
Discharge to Incomati River & - & 107.0 \\
Discharge to streams & - & 153.9 \\
Discharge to Infulene River & - & 8.6 \\
Groundwater abstractions & - & 22.0 \\
Recharge & 358.0 & - \\
Leakage from Incomati River & 4.4 & - \\
Seawater intrusion & 4.5 & - \\
SUM & 366.9 & 366.3 \\
\hline
\end{tabular}

for normal hydrological years. Changes of water budget components were compared with the benchmark model and breakthrough curves of $\mathrm{Cl}$ concentration at key locations were checked for saltwater intrusion impacts (Fig. 12). The water budget changes under different scenarios are presented in Table 4 . The threshold $\mathrm{Cl}$ concentration is taken as $250 \mathrm{mg} \mathrm{Cl}$ per $\mathrm{L}$ following the guideline for drinking-water standard of the World Health Organization (WHO 2003).

\section{Scenario 1: planned new abstractions}

The newly installed pumping wells along the Infulene River (for location see Fig. 13a) were added in the model. The direct impacts are the reduction of groundwater discharge to the Infulene River by roughly $56 \%$ (Table 4). A cone of depression is formed around the well field in the semi-confined aquifer with a maximum depth up to $20 \mathrm{~m}$. The phreatic aquifer in the cone of the depression becomes dry. The $\mathrm{Cl}$ break-through curves at new well locations show an increase in salinity due to saltwater upconing, with the highest concentrations observed towards the south (Fig. 13b), although still below the drinking water standard of the WHO (2003) after 50 years $(250 \mathrm{mg} / \mathrm{L})$. Saltwater upconing occurs at the bottom of the new well locations although the model layers might not be sufficient to compute accurately. 

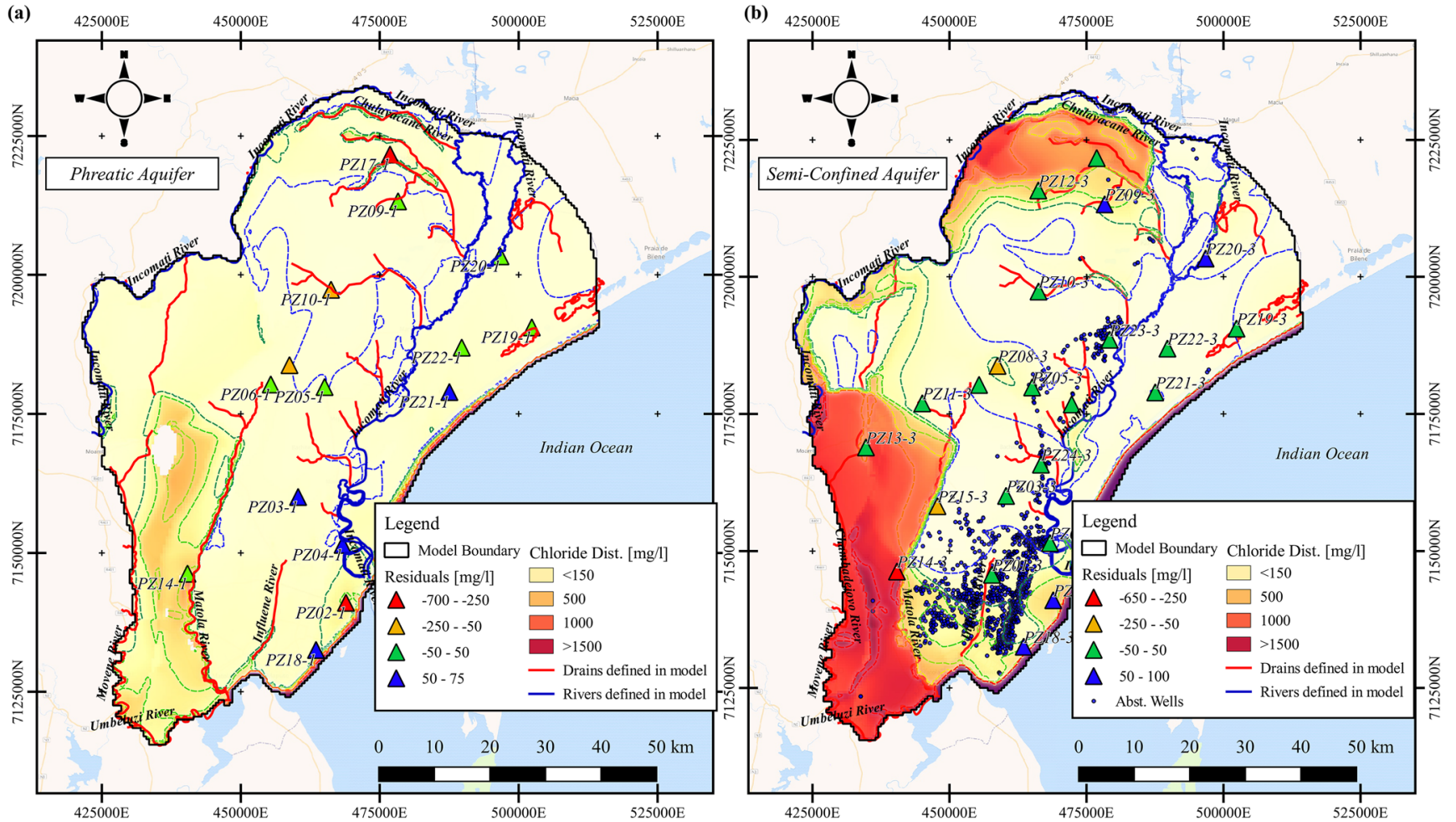

Fig. 12 Simulated $\mathrm{Cl}$ distributions in groundwater in the a phreatic and $\mathbf{b}$ semi-confined aquifers in 2017

Therefore, it might be feasible to operate these new production wells; however, careful monitoring of salinity increase is required to safeguard water supply.

\section{Scenario 2: mean sea-level increase}

Under a sea level rise of $1.0 \mathrm{~m}$, water budget components change slightly, mostly with regard to flow from and towards the sea (Table 4). Chloride concentrations increase along the coastlines mostly within $1 \mathrm{~km}$ inland after 50 years. The sensitive coastal areas for seawater intrusion are located along the Maputo Bay and the Incomati estuary. The coastal area along the Maputo City is much higher than the sea level and is less sensitive to the seawater intrusion.

\section{Scenario 3: projected water demand increase}

The large increase of abstractions has very large impacts on groundwater budget and $\mathrm{Cl}$ concentrations. Comparing to the benchmark model, groundwater levels in the semi-confined

Table 4 Groundwater flow balance under different scenarios

\begin{tabular}{|c|c|c|c|c|c|c|c|c|}
\hline \multirow[t]{2}{*}{ Flow terms } & \multicolumn{2}{|c|}{ Benchmark model } & \multicolumn{2}{|l|}{ Scenario 1} & \multicolumn{2}{|l|}{ Scenario 2} & \multicolumn{2}{|l|}{ Scenario 3} \\
\hline & $\begin{array}{l}\text { In }\left[\mathrm{Mm}^{3} /\right. \\
\text { year] }\end{array}$ & $\begin{array}{l}\text { Out }\left[\mathrm{Mm}^{3} /\right. \\
\text { day }]\end{array}$ & $\begin{array}{l}\text { In }\left[\mathrm{Mm}^{3} /\right. \\
\text { year] }\end{array}$ & $\begin{array}{l}\text { Out }\left[\mathrm{Mm}^{3} /\right. \\
\text { day }]\end{array}$ & $\begin{array}{l}\text { In }\left[\mathrm{Mm}^{3} /\right. \\
\text { year] }\end{array}$ & $\begin{array}{l}\text { Out }\left[\mathrm{Mm}^{3} /\right. \\
\text { day }]\end{array}$ & $\begin{array}{l}\text { In }\left[\mathrm{Mm}^{3} /\right. \\
\text { year] }\end{array}$ & $\begin{array}{l}\text { Out }\left[\mathrm{Mm}^{3} /\right. \\
\text { day }]\end{array}$ \\
\hline Discharge to the sea & 4.5 & 74.7 & 6.8 & 75.2 & 8.0 & 70.5 & 7.7 & 64.5 \\
\hline Abstractions & - & 22.0 & - & 34.6 & - & 22.0 & - & 64.8 \\
\hline $\begin{array}{l}\text { Discharge to stream } \\
\text { (drains) }\end{array}$ & - & 153.9 & - & 150.4 & - & 155.4 & - & 141.2 \\
\hline $\begin{array}{l}\text { Discharge to Infulene } \\
\text { River }\end{array}$ & - & 8.6 & - & 3.8 & - & 9.6 & - & 1.2 \\
\hline Recharge & 358.0 & - & 358.0 & - & 354.8 & - & 358 & - \\
\hline Incomati River leakage & 4.4 & 107.1 & 4.4 & 104.7 & 4.4 & 109.7 & 4.4 & 97.9 \\
\hline Sum & 366.9 & 366.3 & 369.2 & 368.7 & 367.1 & 367.2 & 370.2 & 369.6 \\
\hline
\end{tabular}


a)

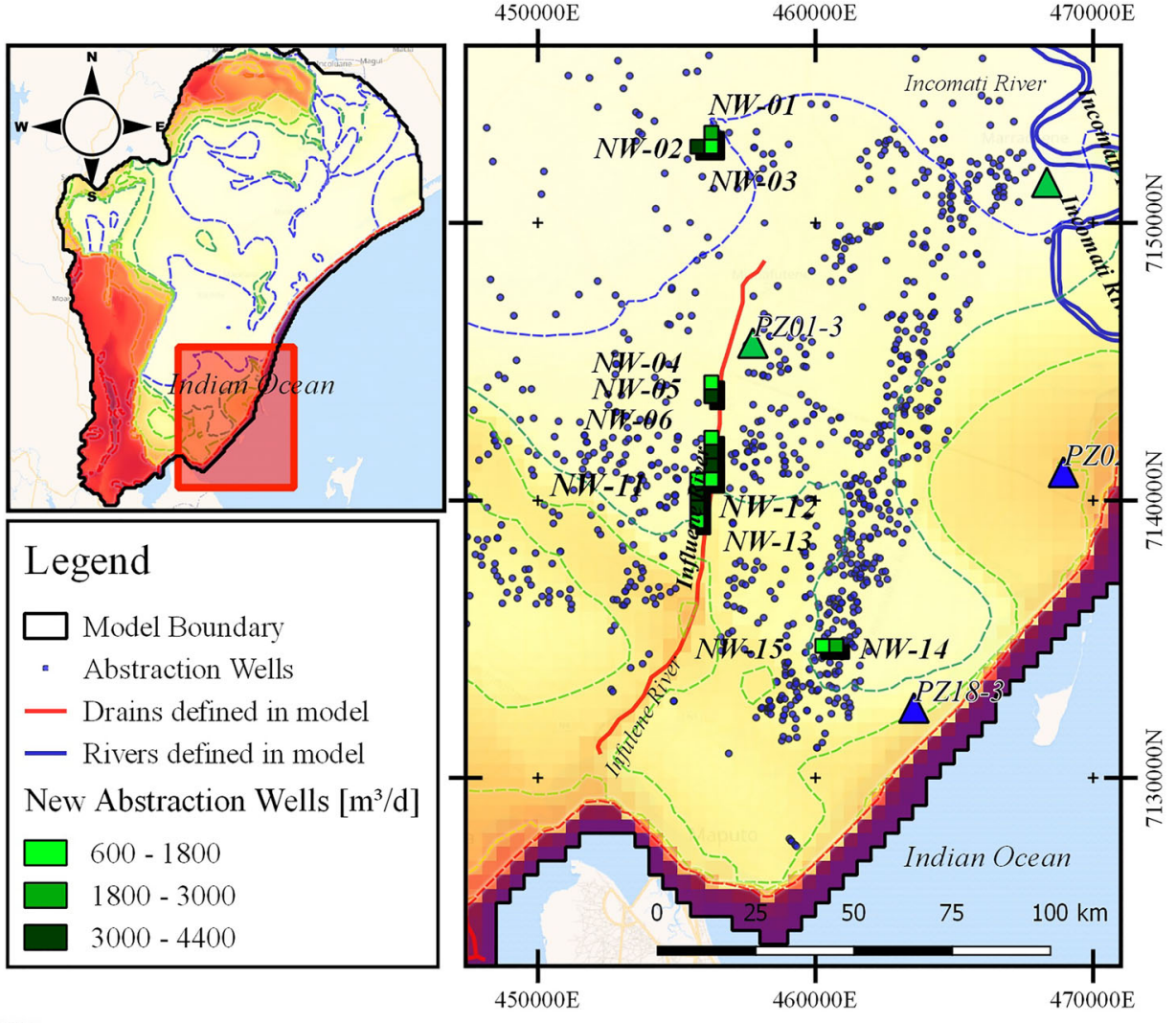

b)

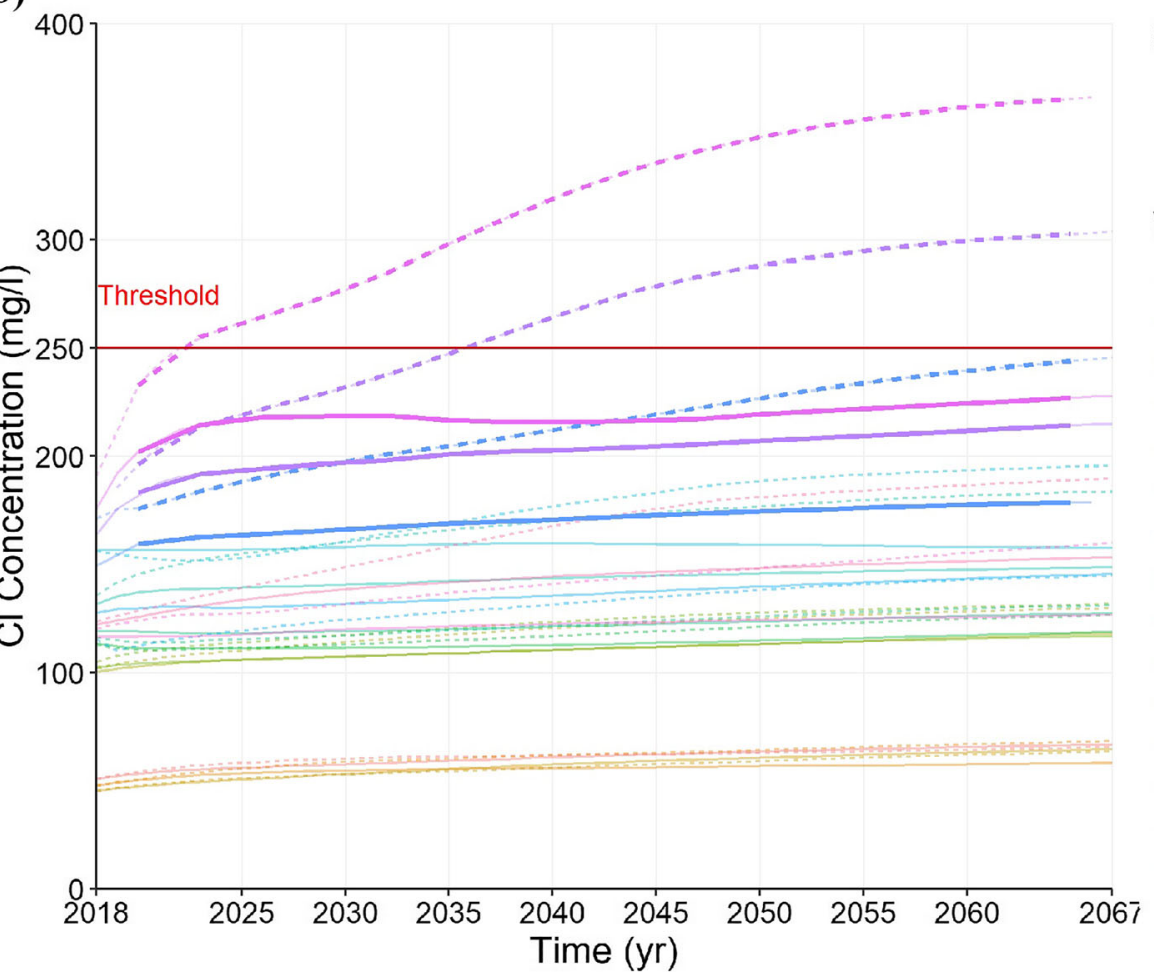

Scenario

- Scenario 1

-. Scenario 3

Well Number

- NW01

- NW02

- NW03

- NW04

- NW05

- NW06

- NW07

- NW08

- NW09

- NW10

- NW11

- NW12

- NW13

- NW14

- NW15

Fig. 13 a Location map of new abstraction wells and $\mathrm{Cl}$ concentrations from scenario 3. b Cl break-through curves at new abstraction wells for scenarios 1 and 3 from 2018 to 2067

aquifer declines $5-40 \mathrm{~m}$ in the urban areas after 50 years (Fig. 14). Groundwater discharges to streams, river and the sea are largely reduced (Table 4). Discharge to the sea is largely reduced resulting in increasing seawater intrusion along the coast. Chloride concentrations in many areas increase beyond the drinking water standard (Fig. 13b). 


\section{Discussion}

\section{Model limitations and uncertainty}

\section{Model structure and discretization}

Sources of uncertainties in groundwater modelling originate from conceptualization of aquifer systems, definition of boundary conditions, parameterization of hydrogeological parameters, and estimation of recharge and discharges (Hill and Tiedeman 2005; Wu and Zeng 2013). The accuracy of the numerical model further depends on numerical model discretization and solution schemes. The conceptualization of the Great Maputo aquifer system into a top phreatic aquifer and lower semi-confined aquifer separated by an aquitard reflects current consensus on regional hydrogeological conditions and supporting data. A bottom aquitard is included in the model since it is a major saltwater source which poses a risk of saltwater upconing into wells in the semi-confined aquifer. The boundary conditions can be clearly identified. Major uncertainties arise from estimation of hydrogeological parameters and recharge and discharges.

The numerical model consists of four model layers, corresponding to two aquifers and two aquitards, and has a uniform cell size of $500 \times 500 \mathrm{~m}$. The model grid might be sufficient to simulate regional groundwater flow and saltwater migrating in aquifers; however, the model grid may be inadequate to simulate freshwater/saltwater transition zones and saltwater upconing. The grid cell size should be reduced and model layers should be increased to simulate these critical zones more accurately.

\section{Model calibration}

The groundwater flow model is reasonably calibrated based on limited measurement data. The flow model reproduced groundwater head contours in agreement with the observed levels and flow directions, and it also computed stream discharges in accordance with the field-estimated values. Better estimation of recharge and long-term measurement of stream discharges and groundwater levels can significantly improve model calibration and reliability.

On the transport model results, the observed overall trend of the saltwater concentration is properly reproduced with some exceptions, despite the several tests made-for instance, PZ093 located in the north of the study area presented higher calculated values which might be attributed to high concentrations seeping into this location with origins in the semi-permeable unit; and PZ15-3 presents lower calculated values that can be associated with the strong drainage effect that Matola River has on this layer. The largest discrepancies, however, were found in PZ17-1, PZ14-3, and PZ-02 for both aquifers. For PZ14-3, the large discrepancy can be a product of the combination of the large concentrations leaving the aquifer through the Matola River with the contribution of a low-estimated initial concentration on either the semi-confined aquifer or the semi-permeable unit. For PZ17-1, a couple of factors can be mentioned: concentrations leaving via the large drainage effect of the Cuenga River, and the accumulation of concentrations due to evapotranspiration in the wetland area, for which the model does not account for.

Similar results were presented by Rojas and Dassargues (2007) for the Pampa del Tamarugal aquifer, in Chile where uncertainty regarding the actual extent of evaporation lead to model overestimations. However, for PZ-02 in both aquifers, the model, which did not capture the observed concentrations, thereby underestimated the phreatic and overestimated the semi-confined aquifer. This might be attributed to large concentrations being accumulated due to evapotranspiration linked to tidal fluctuations substantially increasing these concentrations. Nevertheless, when compared to PZ-04 and PZ18 , being the closest to this particular location, both piezometers present an acceptable calculated-to-observed agreement, indicating potential inconsistencies in the model structure due to the coarseness of the defined model grid and vertical discretization, local formation complexities and transient effects not accounted for. Werner et al. (2013) presents a very good review where these processes, such as transient level variability, sea-level fluctuations, heterogeneous or local complexities, typically constrain seawater intrusion models over regional scales. In spite of this, the overall results need to be treated as an approximation to the actual situation rather than specific concentrations as mentioned by Klager et al. (2014).

\section{Water budget of the Great Maputo aquifer system}

\section{Recharge}

Recharge from precipitation dominates groundwater recharge in the Great Maputo aquifer. No field experiments have been conducted to determine actual recharge values taking into account evapotranspiration. This modelling study suggests that net groundwater recharge is relatively small in comparison to the amount of annual precipitation (3-15\%). However, given the large sensitivity of the recharge term, high uncertainty is associated with these results. Sanford (2002) mentions that considerable uncertainty exists in the current assessment of recharge rates due to spatial and temporal varying landsurface processes and climate. The uncertainty in recharge estimates in this study can be attributed, for instance, to very high evapotranspiration rates resulting from a dry and hot climate and high density of vegetation cover in the area. Thick bushes and patches of trees may intercept large proportions of rainfall and transpire large amount of soil water and groundwater. This is also seen in the hydrochemistry of phreatic groundwater (Nogueira 2017) and in the more detailed rainfall-recharge analysis performed in the study area by Andreetta (2018). The sandy phreatic aquifer becomes dry in 


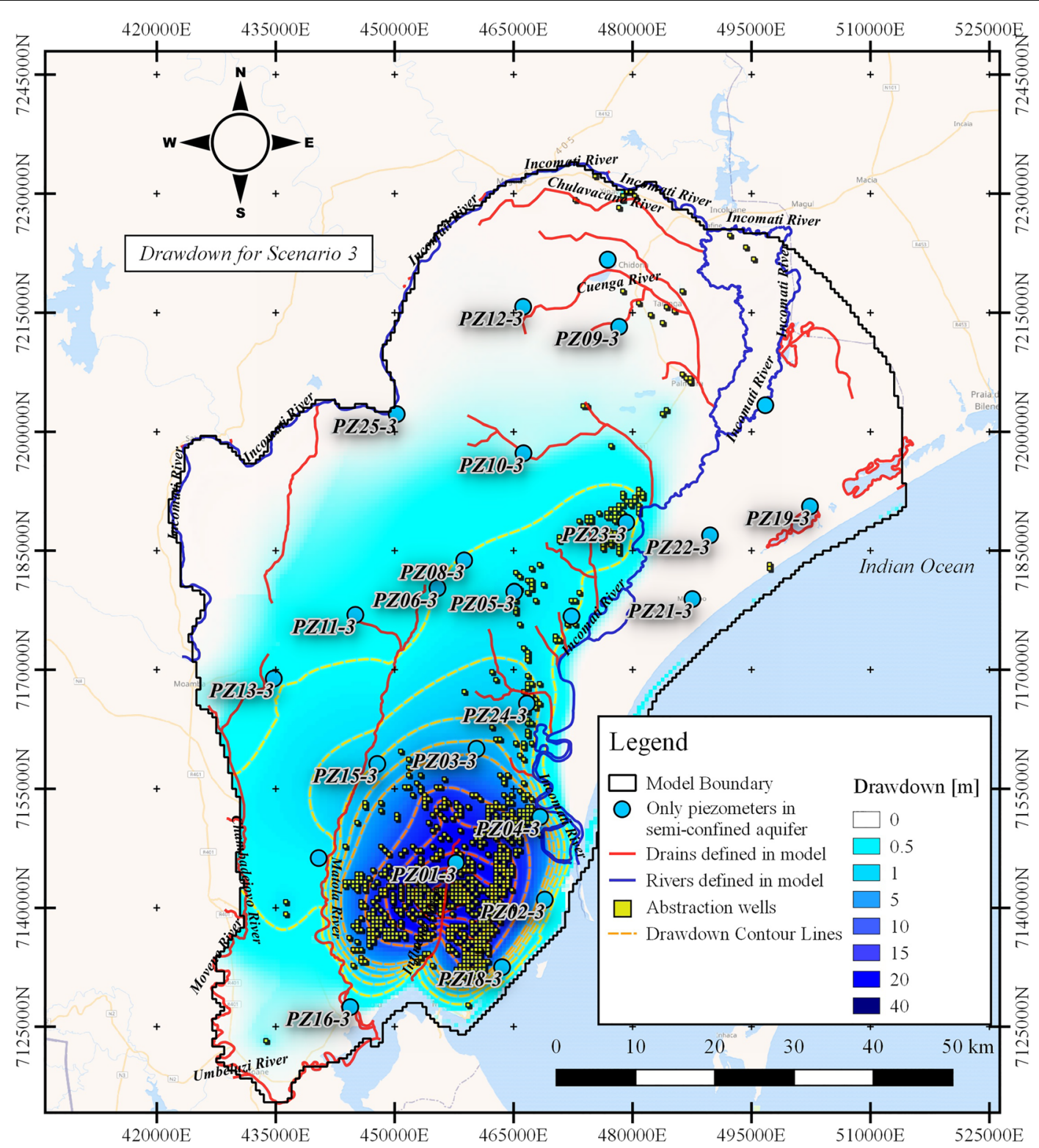

Fig. 14 Effects of groundwater-level decrease (drawdown, DD) in the semi-confined aquifer as a result of increased groundwater abstraction under scenario 3

dry seasons and especially during the dry years and drought periods; however, temporal variations of recharge rates cannot be captured by the current model since flow transient effects were not simulated. From a water-resources-management point of view, land use changes are necessary to reduce the density of vegetation and convert broadleaf trees to desert grasses in order to increase groundwater recharge which can become an important water source to overcome water supply shortages in the area; an important topic for further research.

\section{Discharge to streams}

Significant groundwater discharge to streams occurs in sand dune areas. Groundwater dependent ecosystems are formed along these streams. Since the water table is very shallow in these discharge areas, groundwater can be more brackish due to high evapotranspiration under the semi-arid climate (Alfaro et al. 2017). Fresh groundwater can be abstracted for water supply upstream of discharge areas, while still maintaining groundwater dependent ecosystems. The review of Griebler and Avramov (2015), puts emphasis to the management of these groundwaterdependant ecosystems; however, proper evaluation of groundwater-ecosystem interactions, fluxes and processes is still lacking in this region, which is another interesting topic for future research. Systematic measurements of stream discharges with constructed gauge stations is a first important step. These measurements are useful to infer groundwater recharge and for reliable calibration of groundwater models. 


\section{Management of groundwater abstraction}

Saline groundwater is widely distributed in the area. The major source is saltwater entrapped in past periods of high sea level (Nogueira 2017). Migrating and upconing of entrapped saltwater poses a major threat for fresh groundwater development (Post and Houben 2017; Werner et al. 2017). As the current groundwater abstraction is still small compared to groundwater recharge and natural discharges, there is a large potential for further groundwater development. However, due to salinity problems, concentrated groundwater abstraction with well fields is not recommended, and the impacts were shown in particular for scenario 3. Foldesi et al. (2008) and Kumar (2016) present overviews of strategies for managing groundwater resources from which a more scattered distribution and larger number of production wells with smaller yields would be a better approach in the region. Moreover, abstracting further away from the urban areas, where currently groundwater still largely discharges towards streams and the sea, is also considered a viable alternative (Werner 2010). Currently, the operation by private water providers for peri-urban and rural water supply fits well to the hydrogeological conditions and should be promoted. Management strategies to prevent future water supply shortages and mitigate salinity impacts should consider the use of managed aquifer recharge (MAR) methods for its proven efficiency (Cassanova et al. 2016; Dillon et al. 2019). The constructed models can be used to assess the feasibility of MAR application in the Great Maputo area.

\section{Conclusion}

Groundwater currently provides a good addition to domestic water supply in the Great Maputo area. The centralized public water supply system barely covers the urban area, with frequent interruptions. Groundwater supply provides domestic needs in peri-urban and rural areas. A large supply shortage is foreseen in the near future with rapid increase of urban populations. Groundwater can be a reliable source to meet a part of increased supplies.

Regional groundwater flow and saltwater transport models were constructed based on limited hydrogeological data and preliminary calibrations were performed in this study. The models were used to investigate potential impacts of sea level rise and increased groundwater abstractions. Current groundwater abstractions account for $6 \%\left(22 \mathrm{Mm}^{3} /\right.$ year $)$ of the total discharge; therefore, there is a lot of potential for groundwater resources development in the area. The newly constructed production wells along the Infulene River can be apparently operated for water supply with impacts on the reduction of stream discharges and saltwater upconing. Careful monitoring is thus required. The results of the scenarios analysis suggest that aquifer management strategies must be set up to prevent future water supply shortages and to mitigate potential seawater intrusion impacts. Combining managed aquifer recharge with optimization of pumping practices in which a larger number of scattered production wells are operated with small yields are recommended to avoid saltwater upconing.

The saline groundwater is widely distributed in aquifers and aquitards in the western Matola River and northern areas. The results of this model, together with the hydrochemical analyses behind it, strongly support the hypothesis regarding the existence of fossil saltwater lenses entrapped in the geological history in the Great Maputo region. Saline groundwater is a major factor limiting fresh groundwater development in these areas. Seawater intrusion is a risk only along a narrow costal belt.

Groundwater recharge constitutes a small proportion of annual precipitation in the area, whereas evapotranspiration consumes the largest fraction due to the dry and hot climate in combination with high density of vegetation. For optimal groundwater resources development and management, groundwater recharge can be increased by reducing evapotranspiration though land use changes, and groundwater upstream of discharge areas can be exploited for water supply while maintaining groundwater dependent ecosystems. These are interesting areas for future research.

The development of a transient groundwater flow model is desirable in considering the use of shallow groundwater storage in the phreatic aquifer to meet water demand during the dry seasons which can be replenished during the wet seasons. Despite uncertainties in the model inputs and calibration, the constructed regional groundwater flow and saltwater transport models provided useful information for better management of groundwater abstractions and gained insights regarding dominant hydrological processes and potential impacts of saltwater intrusion. The approach of this case study can be adopted for saltwater intrusion impact analysis in other coastal aquifers.

Acknowledgements The authors thank the Eduardo Mondlane University (UEM) and the Administração Regional de Aguas do Sul (Ara-Sul) for their support and provision of data. Constructive comments from Dr. Koen Zuurbier and an anonymous reviewer are acknowledged.

Funding information The research described in this paper was financially supported by the Dutch Ministry of Foreign Affairs (DUPC) within the framework of the SALINPROVE Project (Mitigating groundwater SALINity impacts for imPROVEd water security in coastal areas under socio-economic and climate change) led by IHE Delft.

Open Access This article is distributed under the terms of the Creative Commons Attribution 4.0 International License (http:// creativecommons.org/licenses/by/4.0/), which permits unrestricted use, distribution, and reproduction in any medium, provided you give appropriate credit to the original author(s) and the source, provide a link to the Creative Commons license, and indicate if changes were made. 


\section{References}

Alfaro P, Liesch T, Goldscheider N (2017) Modelling groundwater overextraction in the southern Jordan Valley with scarce data. Hydrogeol J 25:1319-1340. https://doi.org/10.1007/s10040-017-1535-y

Andreetta R (2018) Impact of climate change on groundwater recharge in Great Maputo aquifer, Mozambique. Quatern Int. https://doi.org/10. 1016/j.quaint.2019.06.024

Ataie-Ashtiani B, Ketabchi H, Rajabi MM (2013) Optimal management of a freshwater lens in a small island using surrogate models and evolutionary algorithms. J Hydrol Eng 19:339-354. https://doi.org/ 10.1061/(asce)he.1943-5584.0000809

Badaruddin S, Werner AD, Morgan LK (2017) Characteristics of active seawater intrusion. J Hydrol 551:632-647. https://doi.org/10.1016/j. jhydrol.2017.04.031

Bakker M, Schaars F (2010) How to become a Jedi master in modeling seawater intrusion with MODFLOW. In: Proc. of the 21st Salt Water Intrusion Meeting, Azores, Portugal, 2010, pp 317-320

Barlow PM, Reichard EG (2010) Saltwater intrusion in coastal regions of North America. Hydrogeol J 18:247-260. https://doi.org/10.1007/ s10040-009-0514-3

Bettencourt P, Jesus CC, Alcobia S, Agra R (2012) SEA and climate change in the coastal zone. IAIA12 Conf, Porto, Portugal, 27 May-12 June 2012, pp 1-5

Cassanova J, Devau N, Pettenati M (2016) Managed aquifer recharge: an overview of issues and options. In: Integrated groundwater management: concepts, approaches and challenges. Springer, Heidelberg, Germany, pp 413-434

Chairuca L, Naafs, A, van Haren I, Upton K, O Dorchartaigh BE (2016) Africa groundwater atlas: hydrogeology of Mozambique. British Geological Survey, Keyworth, UK

Chiang W-H (2005) 3D-groundwater modeling with PMWIN: a simulation system for modeling groundwater flow and transport process, 2nd edn. Springer, Heidelberg, Germany

Coetsiers M, Van Camp M, Walraevens K (2004) Influence of the former marine conditions on groundwater quality in the Neogene phreatic aquifer, Flanders. Proc 18th Sea Water Intrusion Meet (SWIM), Cartagena, Spain, 2004, pp 499-509

De Luca DA, Lasagna M, Gisolo A, Morelli A, Falco M (2019) Potential recharge areas of deep aquifers: an application to the Vercelli-Biella plain (NW Italy). Rend Lincei Sci Fis Nat. https://doi.org/10.1007/ s12210-019-00782-Z

Delsman JR, Hu-a-ng KRM, Vos PC, de Louw PGB, Oude Essink GHP, Stuyfzand PJ, Bierkens MFP (2014) Paleo-modeling of coastal saltwater intrusion during the Holocene: an application to the Netherlands. Hydrol Earth Syst Sci 18:3891-3905. https://doi.org/ 10.5194/hess-18-3891-2014

Dillon P, Stuyfzand P, Grischek T, Lluria M, Pyne RDG, Jain RC, Bear J, Schwarz J, Wang W, Fernandez E, Stefan C, Pettenati M, van der Gun J, Sprenger C, Massmann G, Scanlon BR, Xanke J, Jokela P, Zheng Y, Rossetto R, Shamrukh M, Pavelic P, Murray E, Ross A, Bonilla Valverde JP, Palma Nava A, Ansems N, Posavec K, Ha K, Martin R, Sapiano M (2019) Sixty years of global progress in managed aquifer recharge. Hydrogeol J 27:1-30. https://doi.org/10. 1007/s10040-018-1841-z

Doherty J (2016) PEST: model-independent parameter estimation. Watermark, Brisbane, Australia

Ferguson G, Gleeson T (2012) Vulnerability of coastal aquifers to groundwater use and climate change. Nat Clim Chang 2:342-345. https://doi.org/10.1038/nclimate1413

Ferro BP, Bouman D (1987) Explanatory notes to the hydrogeological map of Mozambique scale 1:1,000,000. Ministry of Construction and Water, Maputo, Mozambique

Foldesi CP, Cyr RC, Spruill RK (2008) Strategies for managing water resources in saltwater intrusion environments. In: 2008 South
Carolina Water Resources Conference, Charleston, SC, October 2008, 5 pp

Griebler C, Avramov M (2015) Groundwater ecosystem services: a review. Freshw Sci 34:355-367. https://doi.org/10.1086/679903

Harbaugh AW, Banta E, Hill MC, Mcdonald MG (2005) MODFLOW2005, The US Geological Survey Modular Ground-Water Model: the ground-water flow process. US Geol Surv Tech Methods 6-A16

Hill MC, Tiedeman CR (2005) Effective groundwater model calibration: with analysis of data, sensitivities, predictions, and uncertainty. Wiley, New York. https://doi.org/10.1002/0470041080

Hill MC, Tiedeman CR (2007) Effective groundwater model calibration. John Wiley \& Sons, Inc., Hoboken. https://doi.org/10.1002/ 0470041080

Hutton JT (1976) Chloride in rainwater in relation to distance from the ocean. Search 7(5):207-208

Hydroconseil, We-Consult (2011) Monitoring MMA aquifer: quantitative and qualitative aspects. We-Consult, Maputo, Mozambique, $77 \mathrm{pp}$

INE (2010) Projecções anuais da população total, urbana e rural 20072040 [Annual projections of the total urban and rural population 2007-2040]. National Institute of Statistics, Maputo, Mozambique

Instituto Nacional de Saúde (INE) (2012) Estatísticas do Distrito da Cidade de Matola [Matola Town District statistics]. INE, Maputo, Mozambique

Jaworska-Szulc B (2009) Groundwater flow modelling of multi-aquifer systems for regional resources evaluation: the Gdansk hydrogeological system, Poland. Hydrogeol J 17:1521-1542. https://doi.org/10.1007/s10040-009-0473-8

Klager BJ, Kelly BP, Ziegler AC (2014) Preliminary Simulation of chloride transport in the equus beds aquifer and simulated effects of well pumping and artificial recharge on groundwater flow and chloride transport near the city of Wichita, Kansas, 1990 through 2008. US Geol Surv Open File Rep 2014-1162

Kumar CP (2016) Sea water intrusion in coastal aquifers. EPRA Int J Res Dev 1:27-31

Lal A, Datta B (2019) Multi-objective groundwater management strategy under uncertainties for sustainable control of saltwater intrusion: solution for an island country in the South Pacific. J Environ Manag 234:115-130. https://doi.org/10.1016/j.jenvman.2018.12. 054

Langevin CD, Thorne Jr DT, Dausman AM, Sukop Michael C, Guo Weixing (2008) SEAWAT version 4: a computer program for simulation of multi-species solute and heat transport. US Geol Surv Tech Methods, Book 6, Chapter A22

Meyer R, Engesgaard P, Sonnenborg TO (2019) Origin and dynamics of saltwater intrusion in a regional aquifer: combining 3-D saltwater modeling with geophysical and geochemical data. Water Resour Res 55:1792-1813. https://doi.org/10.1029/2018WR023624

Michael HA, Post VEA, Wilson AM, Werner AD (2017) Science, society, and the coastal groundwater squeeze. Water Resour Res. https:// doi.org/10.1002/2017WR020851.Received

Mumbere D (2018) Mozambique to restrict water supply as long dry spell looms. AfricaNews. https://www.africanews.com/2018/02/10/ mozambique-to-restrict-water-supply-as-long-dry-spell-looms//. Accessed October 2019

Nelson SA (2013) Coastal zones. http://www.tulane.edu/ sanelson/ Natural Disasters/coastalzones.htm. Accessed October 2019

Nicholls RJ, Cazenave A (2010) Sea-level rise and its impact on coastal zones. Science 328:1517-1520. https://doi.org/10.1126/science. 1185782

Nogueira G (2017) Tracing the hydrochemical water types and salinization mechanisms in the Great Maputo area as a function of groundwater recharge, hydrogeological properties and human activities. UNESCO-IHE, Paris and Delft, The Netherlands

Nogueira G, Stigter TY, Zhou Y, Mussa F, Juizo D (2019) Understanding groundwater salinization mechanisms to secure freshwater resources 
in the water-scarce city of Maputo, Mozambique. Sci Total Environ 661:723-736. https://doi.org/10.1016/j.scitotenv.2018.12.343

Okello AMLS, Riddell ES, Uhlenbrook S, Van der Zaaga P, Jewitch GPW (2012) Isotopic and hydrochemical river profile of the Incomati River basin. UNESCO-IHE, Dept. Water Eng., Delft, The Netherlands. https://www.academia.edu/20386924/Isotopic_ and_Hydrochemical_River_Profile_of_the_Incomati_River_Basin. Accessed October 2019

Oude Essink G, Van Baaren ES, De Louw PG (2010) Effects of climate change on coastal groundwater systems: a modeling study in the Netherlands. Water Resour Res 46:W00F04

Post VEA, Houben GJ (2017) Density-driven vertical transport of saltwater through the freshwater lens on the Island of Baltrum (Germany) following the 1962 storm flood. J Hydrol 551:689702. https://doi.org/10.1016/j.jhydrol.2017.02.007

Post VEA, Werner AD (2017) Coastal aquifers: scientific advances in the face of global environmental challenges. J Hydrol 551:1-3. https:// doi.org/10.1016/j.jhydrol.2017.04.046

Rahmstorf S (2007) A semi-empirical approach to projecting future sealevel rise. Science 315:368-370. https://doi.org/10.1126/science. 1135456

Rödiger T, Magri F, Geyer S, Morandage ST, Ali Subah HE, Alraggad M, Siebert C (2017) Assessing anthropogenic impacts on limited water resources under semi-arid conditions: three-dimensional transient regional modelling in Jordan. Hydrogeol J 25:2139-2149. https:// doi.org/10.1007/s10040-017-1601-5

Rojas R, Dassargues A (2007) Groundwater flow modelling of the regional aquifer of the Pampa del Tamarugal, northern Chile. Hydrogeol J 15:537-551. https://doi.org/10.1007/s10040-0060084-6

Sahoo S, Jha MK (2017) Numerical groundwater-flow modeling to evaluate potential effects of pumping and recharge: implications for sustainable groundwater management in the Mahanadi delta region, India. Hydrogeol J 25:2489-2511. https://doi.org/10.1007/s10040$017-1610-4$

Sanford W (2002) Recharge and groundwater models: an overview. Hydrogeol J 10:110-120. https://doi.org/10.1007/s10040-0010173-5

Schubert R, Schellnhuber HJ, Buchmann N, Epiney A, Griesshammer R, Kulessa M, Messner D, Rahmstorf S, Schmid J (2006) The future oceans: warming up, rising high, turning sour. Special report to the German Federal Government, Berlin

Serdeczny O, Adams S, Baarsch F, Coumou D, Robinson A, Hare W, Schaeffer M, Perrette M, Reinhardt J (2017) Climate change impacts in sub-Saharan Africa: from physical changes to their social repercussions. Reg Environ Chang 17:1585-1600. https://doi.org/10. 1007/s10113-015-0910-2

Shah T, Molden D, Sakthivadivel R, Seckler D (2000) The global groundwater situation: overview of opportunities and challenges. Int Water Manag Inst. https://doi.org/10.5337/2011.0051
Stuyfzand P (1986) A new hydrochemical classification of water types: principles and application to the coastal dunes aquifer system of the Netherlands. In: Proc. Ninth Salt Water Intrusion Meeting, Delft, The Netherlands, 1986, pp 641-655

Tran LT, Larsen F, Pham NQ, Christiansen AV, Tran N, Vu HV, Tran LV, Hoang HV, Hinsby K (2012) Origin and extent of fresh groundwater, salty paleowaters and recent saltwater intrusions in Red River flood plain aquifers, Vietnam. Hydrogeol J 20:1295-1313. https:// doi.org/10.1007/s10040-012-0874-y

Trung NH, Tri VPD (2014) Possible impacts of seawater intrusion and strategies for water management in coastal areas in the Vietnamese Mekong Delta in the context of climate change. Eng Plann Perspect 2014:219-232

Unsal B, Yagbasan O, Yazicigil H (2014) Assessing the impacts of climate change on sustainable management of coastal aquifers. Environ Earth Sci 72:2183-2193. https://doi.org/10.1007/s12665014-3130-z

Vicente EM, Jermy CA, Schreiner HD (2006) Urban geology of Maputo, Mozambique. Geological Society of London, pp 1-13

We-Consult (2011) Development of a groundwater model for the Maputo metropolitan area aquifer report on building the model. We-Consult, Maputo, Mozambique

Werner AD (2010) A review of seawater intrusion and its management in Australia. Hydrogeol J 18:281-285. https://doi.org/10.1007/ s10040-009-0465-8

Werner AD, Gallagher MR (2006) Characterisation of sea-water intrusion in the Pioneer Valley, Australia using hydrochemistry and threedimensional numerical modelling. Hydrogeol J 14:1452-1469. https://doi.org/10.1007/s10040-006-0059-7

Werner AD, Bakker M, Post VEA, Vandenbohede A, Lu C, AtaieAshtiani B, Simmons CT, Barry DA (2013) Seawater intrusion processes, investigation and management: recent advances and future challenges. Adv Water Resour 51:3-26. https://doi.org/10.1016/j. advwatres.2012.03.004

Werner AD, Sharp HK, Galvis SC, Post VEA, Sinclair P (2017) Hydrogeology and management of freshwater lenses on atoll islands: review of current knowledge and research needs. J Hydrol 551:819-844. https://doi.org/10.1016/j.jhydrol.2017.02.047

WHO (2003) Chloride in drinking-water. In: Guidelines for drinkingwater quality, 2nd edn., vol 2. WHO, Geneva

World Bank (2017) “'A Two-Speed Economy’: Mozambique Economic Update.” Retrieved September 28, 2017 (http://www.worldbank. org/en/news/press-release/2017/07/31/a-two-speed-economymozambique-economic-update)

Wu JC, Zeng XK (2013) Review of the uncertainty analysis of groundwater numerical simulation. Chin Sci Bull 58:3044-3052. https:// doi.org/10.1007/s11434-013-5950-8 